\title{
CODING AND BEHAVIOUR OF ESTONIAN SUBJECTS
}

\author{
Helena Metslang \\ University of Tartu and Tallinn University
}

\begin{abstract}
This study is a construction-specific approach to subjecthood in Estonian. It has grown out of Croft's (2001) view that due to the diversity of the syntactic roles' distribution across constructions, there is a need for a shift in grammars to construction-specific syntactic roles. However, in order to compare different arguments, it is also necessary to employ a global cross-constructional subject category. This study treats subjecthood as a set of properties that is represented on arguments to a different degree. The study provides a comprehensive analysis of Estonian prototypical subjects and subject-like arguments (10 in total) from the viewpoint of a large number of morphosyntactic criteria (16). The study is an attempt to apply multivariate analysis on the arguments' syntactic behaviour research. The paper claims that most Estonian subject-like arguments only show subjecthood properties to a limited degree. Supportive data is provided for the Hierarchy of Grammatical Relations Constructions.
\end{abstract}

Keywords: subject, subject-like arguments, grammatical relations, coding, syntactic behaviour, construction grammar

DOI: http://dx.doi.org/10.12697/jeful.2013.4.2.12

\section{Introduction}

Syntactic categories can be defined as "the set of linguistic items that can occupy the same positions in the structures of the sentences of a given language" (Rauh: 2010: 8-9). Different linguistic theories identify syntactic categories on various bases. Rauh distinguishes the extensional and intensional approach to defining syntactic categories. The first simply lists the sets of their members. The intensional approach identifies the set of members of a syntactic category and also describes which properties items must be specified for in order to occupy given positions in sentence structures (ibid.). In order to reveal the multifaceted nature of the subject category in Estonian, both steps are necessary. This paper deals with identifying the distributions of different arguments types in Estonian subjecthood test constructions. This detailed extensional analysis is the first step, which can be further complemented by intentionally oriented studies (see Metslang, to appear). Such language-specific descriptions of syntactic categories 
are a necessary prerequisite for an empirically-grounded linguistic typology pertaining to syntactic category inventories (Gil 2000: 193).

Radical Construction Grammar is a theory that applies a distributions-based view on defining syntactic categories. This theory finds that subjecthood is a language and construction specific phenomenon, a set of properties distributed on the subject-like arguments of different constructions varyingly (Croft 2001: 48-49, 152-153; Barðdal 2006: 77-78). Therefore, when defining a particular grammatical relation (i.e. the syntactic role of a clausal construction; Croft 2001) in a language, the morphosyntactic features that have been regarded as subject tests in linguistics do not necessarily identify the same set of grammatical relations (cf. Bickel 2010: 436-437; Witzlack-Makarevich 2011: 6). In Radical Construction Grammar and related frameworks, the general subject category is treated as a set of more or less close grammatical arguments from various construction environments. The subject(-like) arguments of for example Estonian intransitive and existential clauses possess partially overlapping clusters of semantic, pragmatic, coding and behaviour properties.

In addition to a construction-specific determination of subjecthood, it is also useful to employ a generalized subject category (cf. Siewierska and Bakker 2012; Van Valin 2005: 99). The notion of global cross-constructional subjecthood allows us to analyze the subject as category with a prototype structure (see section 3 ). In this view different arguments (the transitive clause subject, passive subject, the possessee argument of the possessive construction) show a different degree of subjecthood. However, I find it useful to determine construction-specific characteristics of each argument first to ensure precise comparisons.

Major theoretical frameworks find that behavioural properties of arguments have great importance in defining grammatical relations (Siewierska and Bakker 2012: 295). The compatibility of an argument with certain morphosyntactic constructions depends on various factors, for example the argument alignment principles of the language, the arguments' semantics and the possibility of neutralization of different semantic argument types (of the transitive subject, passive subject, etc.) in a language, the topic or role orientedness of the behavioural constructions, or the coding of the argument, etc. (cf. Siewierska and Bakker 2012; Bickel 2004; Kroeger 2004; Van Valin and LaPolla 1997). Different hierarchies have been suggested as factors that determine an argument's realization as a grammatical relation. (At the end of this paper there is a preliminary discussion on the applicability of the Hierarchy of Grammatical Relations Constructions on Estonian subjects.) 
The purpose of this study is to take a step closer to developing a comprehensive picture of subjecthood in Estonian: to revise the proposed set of Estonian subjecthood properties (e.g. Erelt et al. 1993; Hiietam 2003) and to analyze their applicability on different argument types with the corpus data. What makes it the first of its kind is that 10 argument types from (in)transitive, passive, existential, experiential, possessive and resultative constructions are juxtaposed. Close alignment patterns of various similar argument types will be confirmed. The focus is on the behavioural and coding properties, but it will also be necessary to briefly touch on semantics.

The paper consists of 8 sections. Section 2 describes the research methods that are used: multivariate analysis and data retrieval from the corpus. Section 3 outlines the theoretical background for this study. Section 4 lists the clausal argument structure constructions and their arguments whose subject properties are being studied. It also gives a short overview of the theoretical foundations for using clausal constructions as the basis of analysis. In section 5, I will describe the coding properties of Estonian subjects and subject-like arguments. Section 6 discusses the behavioural criteria and shows the distribution of each criterion among the subject-like arguments, which was revealed by the corpus study. In section 7 I will summarize the results and propose some explanations for the alignment patterns of the subject-like arguments I found. The conclusions are made in section 8 .

\section{Method}

This corpus-based study is a multivariate approach to analyzing the distribution of the subjecthood properties in Estonian. Multivariate analysis is a research method that has been proposed for bringing together two different levels of linguistic inquiry: linguistic typology that aims at making large-scale comparisons and generalizations and language-specific research that is interested in describing the diversity without forcing it into a theoretically predefined set of properties (Bickel 2011). To capture the distributions of structural features, one needs to develop sets of variables to measure similarities and differences between languages (or language elements; cf. WitzlackMakarevich 2011: 36-37). According to Bickel the basic idea of multivariate analysis is that

... any similarity between two structures (between or within languages) means that the two structures are identical in some regards and different in other regards. For each relevant 
'regard', one develops a variable (parameter of comparison, tertium comparationis). (Bickel 2011)

Typological multivariate analysis entails the development and analysis of variables that are in a single or multiple relationships with one another. Witzlack-Makarevich (2011: 37) suggests that a properly designed set of variables should be large and fine-grained enough to capture the necessary diversity, and also remain close to the observed linguistic data. If we lump parameters together under a crude variable like 'nominative-accusative alignment', it makes it difficult to compare languages and alignment systems with each other - under this large alignment type, there are smaller systems that have profiles of their own. Similarities between constructions can for example be presented in detailed matrices with primitive variables. This allows one to catch all the relevant properties in a comparable fashion (with each compared item/language receiving the value yes or no for each parameter) (Bickel 2011). In this study, instead of analyzing subjecthood in Estonian in terms of (more vague) family resemblances, I will provide a detailed matrix of all the relevant sub-properties of subjecthood with respect to each subject-like argument type. Multivariate analysis has been used more in the research on argument coding, while the present study is also applying the methodology on argument behaviour.

The data of this study has been drawn from the balanced sub-corpus of the Corpus of Written Estonian which contains fiction, media and scientific texts (15 million words of morphologically annotated text). To a lesser extent, some preliminary quantitative data will be used for analyzing argument coding (about 2000 sentences in total; see section 5). To study the 11 behaviour constructions, I found via repeated searches a total of 1200 examples. ${ }^{1}$ In the case of a few rare phenomena, the author employed the use of the internet and introspection. The resulting corpus of behavioural features is generally balanced: I have included a comparable amount of examples of each argument type in each test construction. The analysis on the syntactic behaviour constructions is qualitative because the semantic part of the analysis had to be done manually - no statistics are presented here. Nevertheless I have tried to provisionally distinguish the more productive constructions from the constructions with marginal usage (see section 6) on the basis of whether a search yielded only a few examples, or the opposite where there were numerous cases showing a

1 A number of methods were used to obtain behavioural examples from the corpus, e.g. searches by the verb lexeme, by the infinitival or other verb forms (lexeme + suffix or just the suffix) or by the combinations of both (sometimes with an accompanying nominal element), by the reflexive pronoun, etc. 
variation in form and meaning. I performed different searches until I was convinced that the construction is either used with the argument under scrutiny (i) rather or very productively in the corpus, (ii) very marginally or only with a subpart of the argument type or (iii) not at all. To make the results comparable, I used a scoring system, assigning each argument 2,1 or 0 points in each test. In the course of the analysis, when whichever argument under scrutiny has a subjecthood property, I will conclude that this particular test further adds to the argument's subjecthood score. As arguments' coding properties are one of the most widely studied topics of Estonian grammar, the analysis of coding properties in this study mainly relies on earlier research.

\section{Background}

The treatment of Estonian subject-like arguments can be best systematized by using Bickel's (2004) synopsis on the asymmetric organization of participants. He shows that in not all participants are equal in linguistic representation; in most situations some participants are more prominent than the other(s). Such asymmetry can affect grammar in various ways. The more prominent arguments tend to gravitate towards topical positions; they are privileged antecedents for reflexivization and other anaphora. However, Bickel argues that "languages vary considerably as to whether or not they take this further, i.e. as to whether morphology and syntax too treat these arguments as prominent ones" (Bickel 2004: 77). Prominent morphological and syntactic treatment is close to Keenan's (1976) division of subject features to coding and behaviour (i.e. encoding the participants of the events vs. making reference to participant roles, e.g. to the most actorlike argument of the transitive clause; Croft 2001: 148-149). ${ }^{2}$ For example, the Estonian experiencer arguments can receive prominent treatment on the pragmatic level (they are topics) and by coding (they are preverbal) but not on the syntactic behaviour level (e.g. they cannot participate as controllees in control constructions; see section 6).

According to Radical Construction Grammar, constructions serve as the basic units of syntactic representation; categories (for example the subject or object) are not primitive units but are derived from the construction(s) in which they appear (Croft 2001: 4; see also Siewierska and Bakker 2012). In language, parts of constructions are not isolated; they only occur in use, i.e. in constructions (Barðdal 2006: 77). The inventory of constructions in a language (e.g. idioms,

2 Instead of $\mathrm{O}$, Croft uses the abbreviation $\mathrm{P}$. 
sentence type constructions, subcategorization frames, control constructions, case and agreement constructions and lexical items; cf. Bickel 2010; Croft 2001) is varied according to the degree of schematicity and the taxonomic links or relationships between them.

To determine the spread of subjecthood in Estonian, I analyze two different groups of constructions: the constructions that contain the arguments whose subjecthood I am measuring (transitive, passive, experiential constructions, etc.) and the constructions that I regard as reflecting subject properties (raising, control, etc.). The former, syntactic clause level construction types have been characterised in terms of cognitive schemas that are templates or abstract prototypes in Helasvuo (2001; see the next section). The latter, the constructions that are used to define a syntactic category are typically called argument tests or criteria for the category in question (Croft 2001: 13). I use the terms criterion, test or property to refer to this type and the terms clausal construction or argument structure construction for the former.

Barðdal (2006: 77) warns that caution should be applied when using these test constructions as a subjecthood measure, as the subject tests are mere constructions of their own. The attribution of a certain property to an argument only tells us something about "the constructions encoding those roles and the conceptual space onto which the constructions are mapped" (Croft 2001: 134), and does not let us make any further generalizations. Therefore I have attempted to find as many criteria as possible to give a multifaceted view of the subject properties.

It is characteristic to morphosyntactic realization of arguments that they can be aligned with each other and so "they can receive the same treatment by a specific construction, e.g. so that they can all trigger the same agreement paradigm on the verb, or so that they can all be assigned the same case marking" (Bickel 2010: 403-404). Hence, different subject-like arguments align with each other differently with respect to various subjecthood tests. For example, the Estonian active transitive subject and the subject of the passive clause behave similarly with respect to case-marking in negation (Torn-Leesik 2009) but differently in the subject control construction with the supine (see section 6). Compare:

(1) Peeter ei söö-nud õuna. P.N NEG eat-PST.PTC apple.P 'Peter did not eat an apple.' (Transitive subject, nominative in negation) 
(2) Võti ei ol-nud pööningu-le peide-tud. key.N NEG be-PST.PTC attic-ALL hide-PASS.PST.PTC 'The key was not hidden in the attic.' (Passive subject, nominative in negation $)^{3}$

(3) Mul ei ole võti-t. I-AD NEG be key-P 'I do not have a key.' (Possessee of the possessive clause, partitive in negation)

(4) Kogemu-s, mis ulatu-b puuduta-ma alateadvuse experience that extend-3SG touch-INF subconsciousness.G kiht-e. layer-P.PL

'An experience that has extended to touch the layers of subconsciousness.' (Transitive subject, subject control with a supine)

(5) *Arve lähe-b maks-tud ole-ma. bill.N go-3SG pay-PASS.PST.PTC get-INF Intended: 'The bill will go to be paid.' (Passive subject, impossibility of subject control with a supine)

Both the active transitive and passive subject retain their nominative marking in negation, unlike the possessee of the possessive clause. The transitive subject can be the controllee of the supine control construction (the obligatorily deleted coreferent argument of the lower clause) but the passive subject cannot be.

Traditionally the coding properties (e.g. agreement and case) have been considered superior in defining the Estonian subject. The previous examples raise the question, why one set of properties should be preferred over others. Such bias in methodology has been criticised by some authors (e.g. Croft 2001: 45). Instead of neglecting some criteria, it is considered more accurate to take all relevant properties into account without prioritizing them (Witzlack-Makarevich 2011: 6). However in the current analysis this method also shows problems. For example, some criteria are rules that (almost) always apply (e.g. case in negative clauses) whereas some criteria are only statistical, representing probabilistic tendencies (e.g. zero-anaphora; see section 5). Also there is a threat of the overall picture of subjecthood being distorted if one has identified a number of tests that actually all reflect

3 If the preverbal NP is in the partitive then it is analysed as the object of the impersonal construction. On the difference of Estonian personal passive and impersonal clauses, see section 4 . 
the same underlying property (see the discussion in section 6). Nevertheless I find starting with taking all criteria into account more illuminating.

The aim of this analysis is not to give judgements of whether any of the studied arguments (apart from the prototypical subjects, see below) is a subject or not. Instead this paper looks at the spread of different subject properties, because strict categorizing (that is in fact just a question of labelling) may not always be useful (cf. Croft 2001: 50 ). This view was also adopted in the closely related language of Finnish by Hakulinen et al. (2004: §922) and Hakulinen (1983) who reached the understanding that uniform subject category is inapt in Finnish. Hakulinen describes the manifold use of morphosyntactic subject features (or, using the terms adopted here: test constructions) in Finnish as follows:

... sometimes the features pile on a single constituent of a clause, sometimes these features are not needed in the clause, sometimes they distribute evenly on the constituents around the verb, sometimes there are only few of them. (Hakulinen 1983: 250)

As will be seen in the present analysis, this description is also suitable in the case of Estonian.

The cross-constructional, global subject category is taken as a category with the prototype structure (cf. Taylor 1995) in this paper. The paper uses the notion prototypical subject against which various subject-like arguments are evaluated. One option of determining prototypical categories is in the vein of Haspelmath (2002): via complexity, which is, in turn, related to usage frequency. Prototypical categories are used most frequently, and they therefore tend to show the greatest syntagmatic simplicity and paradigmatic complexity across languages (ibid.: 22). I have defined the prototypical subject in Estonian broadly and regard it being central in the sense of coding, semantics and the construction types it occurs in. I consider the prototypical subject the sole core argument of the active intransitive clause and the most actorlike argument of the active transitive clause. ${ }^{4}$ The prototypical subject is in the nominative, and the predicate verb agrees with it. Following Barðdal (2006) I use the term subject-like argument to denote these arguments that partly deviate from the prototypical subject: they do not share all the central properties mentioned above. Before I continue

4 Also the earlier studies on subjects' behavioural features in Finnish have utilized this notion prototypical subject (Hakulinen 1983: 250). The concept matches partly with Goldberg's (1995) view on the polysemy of constructions: constructions tend to have central senses and their modifications. The central sense is not abstract, constructions rather have a number of related meanings, one of which is central (e.g. in ditransitive constructions the central meaning is transfer, the modifications of it are intended and promised transfer). 
with introducing the data, I would like to make some remarks as to the choice and application of subjecthood criteria and on previous studies of the subject's behavioural properties concerning Estonian and Finnish

When making decisions on the degree of subjecthood, I only measure the subject-like arguments against the criteria that are widespread among prototypical subjects and that are not present or (mainly in the case of some coding properties with a statistical nature) rarely present in the case of objects. The arguments are not measured against any properties that are only characteristic of the (non-prototypical) subject-like arguments.

Earlier studies on the behavioural properties of most of these arguments in Estonian include Erelt (2004), Erelt et al. (1993), Erelt and Metslang (2006), Hiietam (2003), Koks (2004) and Lindström (2012). However, these studies do not give a full systematic picture of the syntactic subjecthood properties in Estonian. There is also still a need for a comprehensive account that compares this abundant network of syntactic relationships more thoroughly with coding information across several construction types.

The most concise study in Estonian has been conducted by Erelt et al. (1993) who have described in detail various control and raising constructions and reflexivization. However, their focus is not on describing syntactic subjecthood properties but the individual infinitival, reflexive constructions, etc. Hence there is no unified discussion of subject behaviour. Unlike Erelt et al. (1993), Hiietam's (2003) purpose of the analysis of several coding and behaviour properties is to determine the Estonian subject. Her choice of arguments under scrutiny is similar to the one adopted here; in addition to the argument types analyzed by Hiietam, I am looking at the arguments of the source-marking resultative construction (see below). Her choice of criterial constructions includes case, agreement, word order, negation, subject control, object control, subject-to-subject raising and reflexivization. The present analysis revises some of her suggestions by using corpus analysis and also adds the data of zero-anaphora, subject-toobject raising, some more specific control constructions, the antecedence of possessive pronouns and impersonalization.

Hakulinen et al. (2004) state that in Finnish, the common behaviour property of the basic subjects and the topical arguments of marked clauses is participation in the raising constructions with the verbs uskoa 'believe' and sallita 'allow' (the term basic subject denotes a concept similar to what is called prototypical subject in this paper). However, in Finnish raising constructions, the basic subjects get genitive marking while the other arguments retain their finite 
clause case-marking. Only the basic subjects can be passivized ${ }^{5}$ and occur in the subject control constructions with the verbs haluta 'want' and pyrkiä 'try'. They find that being the antecedent of a reflexive pronoun or a possessive suffix is not a subject property but rather indicate topichood (ibid.). The Estonian counterparts of all these criteria will be discussed in section 6 . See also the discussion on the semantics of the Finnish and Estonian subject at the end of section 4.

\section{Subjects, subject-like arguments and clause types in Estonian}

The coding properties of the prototypical Estonian subject, in addition to the aforementioned ones (the nominative case, person and number agreement with the verb and preservation of nominative in negation) are the neutral preverbal position and the possibility of zeroanaphora (see section 5). The occurrence of all these properties largely depends on the clausal, syntactic construction type.

For comparison, the Estonian object is subject to the bounded-unbounded case-marking system: partitive marking denotes the imperfective aspect or unbounded object referent or both, genitive or nominative marking denotes perfective aspect occurring together with a bounded object referent. In the case of Finnish, Kiparsky (1998) unites the verbal and nominal aspects and calls the first use the unbounded VP and the second use the bounded VP. The nominative object can occur in the plural and in (generally) subjectless clauses (imperative, impersonal and some infinitival constructions). In negation, the object takes the partitive case (Erelt et al. 1993: 51-52). For example:

(6) Mari söö-b küpsis-t.

Mari.N eat-3SG biscuit-P

'Mari is eating a biscuit.' (partitive object with imperfective aspect)

(7) Mari sõ-i küpsise ära. ${ }^{6}$

Mari.N eat-PST.3SG biscuit.G up

'Mari ate a biscuit.' (genitive object with a bounded referent and perfective aspect)

(8) Mari ei söö-nud küpsis-t.

M.N NEG eat-PST.PTC biscuit-P

'Mari did not eat /was not eating a biscuit.' (partitive object in negation)

5 The term passive is used according to the Finnish tradition here. It greatly resembles Estonian impersonal.

6 The clause would also have a perfective meaning without the perfectivity particle ära, however speakers usually prefer to use it. 
(9) Küpsis söö-di ära.

biscuit.N eat-IMPS.PST up

'The biscuit was eaten up.' (nominative object in impersonal)

The realization of Estonian arguments is largely tied to syntactic construction types, also called basic simple sentence clause types (Erelt and Metslang 2006; see also Erelt et al. 1993; Huumo 1993; Erelt 2005; Nemvalts 2000). Helasvuo (2001: 4-8) maintains that the utterances containing syntactic construction types often instantiate the prototypical schemas only roughly and may differ from them with respect to a certain parameter; the instantiation of schemas depends on their position in the discourse sequence, memory factors, etc. The emergence of cognitive schemas is explained by the processes of entrenchment and conventionalization (ibid.). The Estonian construction types are first of all distinguished by the way the main clausal topic and its accompanying circumstances are realized (Erelt and Metslang 2006). By accompanying circumstances the authors mean several morphosyntactic, semantic and information structural properties. Their approach divides clause patterns in two basic types: unmarked basic clauses and marked basic clauses. The unmarked basic clauses (see example 10 below) are multifunctional and the main clausal topic is realized as the fully grammaticalized nominative subject (ibid.: 254). The marked basic clauses (e.g. of the existential construction) are monofunctional and, as Erelt and Metslang suggest, the clausal topic is not a fully grammaticalized subject but an adverbial, oblique or direct object. In the framework of construction grammar both the unmarked and marked basic clause type can be regarded as highly schematic argument structure constructions. However, the term clause type is a convenient means to distinguish these patterns and will be used throughout this paper.

Helasvuo suggests that in addition to the grammaticalization of particular arguments, some schemas are themselves more grammaticalized and some less so (for example transitive vs. existential schema respectively that represent unmarked and marked constructions). In the transitive construction, the realization of the subject is defined in very abstract grammatical terms. The construction does not have lexical specifications for the predicate verb and the word order is highly flexible. However, Helasvuo shows that the existential construction has a much less grammaticalized schema. There are lexical restrictions as to which verbs can participate in the construction, the word order and realization of the NPs are dependent on the construction or particular verb lexemes (i.e. on less general level phenomena), and the word order is rather fixed (2001: 5-8). Although Helasvuo is dealing with 
spoken Finnish, similar grammatical principles seem to apply in Estonian, and also in written discourse.

In Estonian, several clausal constructions that express possessive relations, existence, experience and result can usually be analyzed as belonging to the group of marked (monofunctional) basic clauses. The semantic function of these constructions is quite specific; hence they are, in the sense of construction grammar, less schematic than the unmarked (multifunctional) clauses.

In the analysis, I will look at the subjecthood properties of ten argument types from seven clausal constructions. I have chosen to identify the relevant arguments on the basis of construction types and in most cases not (verbal) predicate classes, because most argument types occur with a wide array of predicate verbs (the exception here are the experiential and resultative constructions, see below). In some construction types the use of the copula olema 'to be' is widespread. It is of course impossible to use this verb as a basis of defining grammatical relations, as it allows for great variation. This study looks at the following construction types:

- The transitive, intransitive and passive subjects of the unmarked basic clause type. The transitive clause has a $N-V-$ $P / G / N-(X)$ structure (i.e. the clause containing as obligatory arguments the nominative subject, the predicate verb and the object that can either be in the partitive, genitive or nominative. Some transitive clauses also have one or two additional obligatory NPs). The intransitive clause and the passive clause have a $N-V-(X)$ structure (i.e. the clause containing as the obligatory argument the nominative subject and the predicate verb. Some intransitive and passive clauses also have additional obligatory $\mathrm{NP}(\mathrm{s}))$.

- The sole argument of the existential construction with a (Loc) $V-N / P$ structure (i.e. the basic clause containing as the obligatory components the predicate verb and a nominative NP, whose referent is being introduced into the discourse and that can take the partitive under certain circumstances. Usually there is also an NP or PP in the clause marking the location).

- The possessor and possessee arguments of the possessive construction with a $A D-V-N / P-(X)$ structure (i.e. the basic clause containing as the obligatory components an adessive NP with the possessor meaning, the predicate verb olema 'to be' and a nominative NP with the possessee meaning that can take the partitive under certain circumstances. In some such constructions there is also another obligatory NP). 
- The experiencer and stimulus arguments of the experiential construction with an $A L L-V-N / P-(X)$ structure (i.e. the basic clause containing as the obligatory components an allative (sometimes interchangeable with the adessive) NP with the experiencer meaning, the predicate verb, a nominative NP with the stimulus meaning that can take the partitive under certain circumstances. In some constructions like this, there is also another obligatory NP or adjective).

- The two arguments of the source-marking resultative (change of state) construction with a $E L-V-N / P$ structure (i.e. the basic clause containing as the obligatory components an elative NP marking an entity that changes its state, the predicate verb and a nominative NP marking the resultant state that can take the partitive under certain circumstances). ${ }^{7}$

The corpus examples that have been classified under these construction types show great variation in terms of the existence and number of additional arguments in the clause and their degree of obligatoriness, word order, ellipsis interpretation, and semantics, among other things. Categorizing constructions entails making several decisions by the linguist, which may cause subjectivity. Therefore these construction types are inevitably vaguer than the test constructions. I will give more thorough descriptions of each type below.

\section{Transitive construction $N-V-P / G / N-(X)$}

The transitive construction belongs to the unmarked basic clause type. The obligatory arguments of the clause are the nominative subject, the predicate verb that agrees with the subject, and the object with a complex case-alternation system (see above). The argument under study is the subject, which usually coincides with the semantic argument A (the most actor-like argument of the clause). In some cases, the subjects and subject-like arguments will also be contrasted with the object $(\mathrm{O}$, the not most actor-like argument of the transitive clause). For example:
(10) Konditsioneer
(A) liiguta-s
õhku (O).
air.conditioner.N
move-PST.3SG air.P
'The air conditioner moved the air (around).'

Some transitive clauses also have an additional obligatory argument.

7 Cf. Erelt and Metslang (2006: 260). 


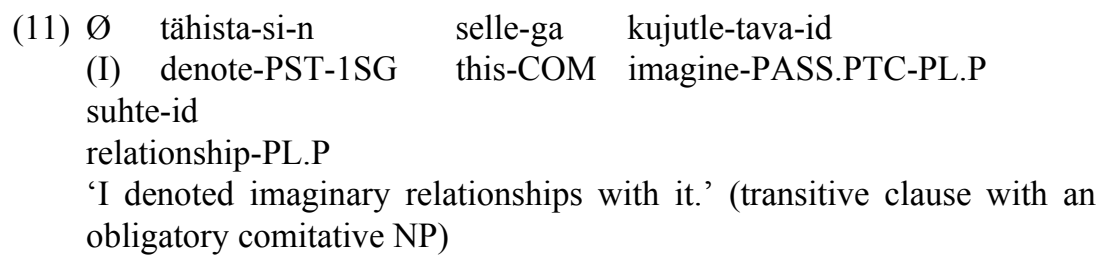

\section{Intransitive construction $N-V-(X)$}

The intransitive clause also belongs to the unmarked basic clause type. In this study I look at the subjecthood properties of the intransitive subject, i.e. the sole argument of an intransitive clause (the participant role: S).

(12) Rong (S) peatu-s.

train.N stop-PST.3SG

'The train stopped.'

I also included the cases where there was another obligatory NP in the clause:

(13)

Helistamise mõte (S) pol-nud kõne sisu-s. calling.G point.N be.NEG-PST.PTC phone.call.G content-IN 'The point of calling was not in the content of the phone call.' (intransitive clause with an obligatory inessive NP)

When studying the arguments' behavioural properties, I also checked if there are any differences between the intransitive subject's semantic variants ( $\mathrm{S}$ of an agentive situation, undergoer $\mathrm{S}$ and $\mathrm{S}$ of static situations). All these semantic variants, however, passed all the subjecthood tests and I was unable to identify any grammatical differences between them.

\section{Passive construction $N-V-(X)$}

Derived arguments are sometimes treated on par with non-canonically marked arguments (e.g. Onishi 2001: 22). Although the passive may be regarded as a different level construction than the other ones under analysis, I have included it in this study, as the derived subject (d-S, which is the term used by e.g. Van Valin (2005)) is clearly idiosyncratic and its properties are worth comparing to the other subjectlike arguments. ${ }^{8}$ The passive is the key to semantically variable

8 Although Construction Grammar is not a derivational theory I choose to use this term as it emphasizes the proximity of the passive and intransitive subjects - a fact that will be shown by the present analysis. 
syntactic pivots (Van Valin and LaPolla 1997: 282): it is not only actors but also undergoers like passive subjects that tend to receive highly subject-like treatment.

In Estonian one can find both the resultative (personal) passive and the impersonal categories. In this study I analyze the subjecthood properties of the passive subject (d-S) and I use the possibility of impersonalization, as a general subjecthood criterion. Torn-Leesik (2009) distinguishes these two construction types by verbal morphology, the choice of verb lexemes, the case in negation and the use of agentive obliques.

Both transitive and intransitive verbs can be impersonalized, but only transitive verbs can be passivized. The impersonal forms are marked by -takse, -dakse or -akse (present), -ti or -di (past).

$\begin{array}{llll}\text { Tartu-s tantsi-takse } & \text { oma linna } & \text { samba-t. } \\ \text { Tartu-IN dance:impers.pres } & \text { own } & \text { town.gen } & \text { samba:part } \\ \text { 'People are dancing their own samba in Tartu.' (Torn-Leesik 2009: 73) }\end{array}$

The characteristics of the impersonal are the deletion of the subject (it is seldom demoted), the lack of object promotion (it preserves its object properties, e.g. the partitive case) and in general the lack of person and number agreement on the verb. In the perfect tenses, the building blocks of the impersonal form (the auxiliary olema 'to be' and the passive participle) coincide with the passive (ibid.: 74).

(15) On

loe-tud raamatu-t.

be.pres.3 read:pass.ptc book:part

'One has read the book (but not finished it).' (impersonal; Erelt et al. 2000)

Torn-Leesik shows that in the case of the passive, the active subject is demoted or deleted and the active object is promoted to the subject of the passive. It receives the nominative case and agrees with the verb in number and person (ibid.: 82 ). ${ }^{9}$ Therefore I treat the passive construction as belonging to the unmarked basic clause type. The passive subject always occurs in the nominative, while the impersonal object can occur in the partitive or nominative (but unlike personal objects not in the genitive). When the impersonal object takes, similarly to other objects, the partitive in negation, then the passive subject stays in the nominative.

9 cf. Aarts (2010: 178) for the ways to distinguish between passive constructions and nonpassives (verbal and adjectival constructions). 
$\begin{array}{lllll}\text { (16) Se-da } & \text { artikli-t } & \text { ei } & \text { avalda-tud } & \text { ühe-s-ki } \\ \text { this:part } & \text { article:part } & \text { neg } & \text { publish:pass.ptc } & \text { one:in:cltc } \\ \text { tõelise-s } & \text { ajakirja-s } & \text { või } & \text { nädalalehe-s } & \\ \text { real:in } & \text { magazine:in } & \text { or } & \text { newspaper:in } & \end{array}$

'This article was not published in any real journal or newspaper ...' (impersonal with negation)

(17) Nei-d, kelle nime-d Riigi Teataja-s ei ol-nud those:part whose names:nom Riigi Teataja:in neg be:act.ptc avalda-tud, ilmselt ei vallanda-tud. publish:pass.ptc apparently neg sack:pass.ptc

'Those, whose names were not published in the Riigi Teataja, apparently were not fired.' (passive with negation)

(Torn-Leesik 2009: 74, 75.)

A feature of negation in Estonian is that the predicate verbs lack agreement features in it (in person and number). The passive constructions under scrutiny in this study may contain an additional obligatory oblique NP.

Existential construction $(L o c)-V-N / P$

As the first example of the marked basic clause type, I will look at an existential construction, see examples 18-20. Such constructions are used to present a new referent in discourse and to characterise the location (e.g. Nemvalts 2000). The existential constructions under scrutiny usually consist of a topical locative phrase (adverbial, can also express other circumstances, like time), a post-verbal indefinite subject-like NP (following Helasvuo 2001: existential NP or e-NP) and a predicate verb (olema 'to be' or almost any intransitive verb, used in the way that existential meaning is put into the foreground).

(18) Ja korraga torka-s mu-lle pähe veider and suddenly strike-PST.3SG I-ALL head.ILL strange.N.SG mõte (e-NP).

thought.N.SG

'And suddenly I got this strange idea.' Lit. 'And suddenly a strange idea struck me in the head.' (nominative e-NP with the referent's inclusive quantity)

(19) Alatihti juhtu-s tema-ga isegi õnnetus-i (e-NP). often happen-PST.3SG s/he-COM even accident-P.PL

'Often even accidents happened with him.' (partitive e-NP with the referent's non-inclusive quantity) 
(20) Bussijaama-s ei seisa seina-l kunagi rongi-de bus.station-IN NEG stand wall-AD never train-G.PL sõiduplaani (e-NP). schedule.P

'The trains' schedule is never on the wall in the bus station.' (partitive e-NP with negation)

The coding of the existential e-NP has some subject features. It usually bears the nominative case (the nominative-partitive case-alternation of the e-NP is dependent on quantitative indefiniteness, polarity and pragmatic implications; Metslang 2012; Nemvalts 2000) and it can trigger agreement on the verb. With respect to agreement the clear cases are the plural nominative e-NPs that trigger agreement (see example 41 below) and the plural partitive e-NPs that do not (19). However, the e-NP is usually in the singular (about two thirds of the cases; Metslang, to appear), either in the nominative or the partitive. In this case the verb is in the unmarked third person singular form (if we leave aside the extremely rare uses of first and second person pronouns as e-NPs), which can be regarded the default form that is a less clear sign of agreement. Also in many other respects, the e-NP is the opposite of the subject of unmarked clauses (Erelt et al. 1993: 41; Tael 1988b: 141; Helasvuo and Huumo 2010: 168 on Finnish). ${ }^{10}$

In this study, also the existential constructions without a locative phrase have been taken into account (either due the ellipsis of contextually given reference or because the function of the clause is just presenting an entity in the discourse without reference to location, time or the like).

\section{Possessive construction $A D-V-N / P-(X)$}

The second simple marked clause construction is the possessive construction (see examples 21 and 22). The clauses included in the analysis have both the usually topical possessor argument (Pr) in the adessive case and the usually postverbal possessee $(\mathrm{Pe})$ that is subject to nominative-partitive case alternation. They also have the verb olema 'to be' that agrees with the Pe. The case-alternation of the Pe depends on the same factors as the e-NP of the existential construction.

10 There is a discrepancy in Estonian and Finnish linguistics in determining existential sentences. In Finnish linguistics these existential-like sentences that contain nominative postverbal NP that agrees with the verb have been analyzed as intransitive clauses. In the case of Estonian these clauses have been categorized as existential due to pragmatic and semantic reasons. Helasvuo and Huumo's (2010) analysis is another argument for following the Estonian tradition here: the existential sentences with nominative and partitive NP-s are often almost indistinguishable in meaning (Erelt et al. 1993: 44). 
(21) Ta-1 (Pr) ol-i s/he-AD be.PST.3SG red.N car.N

'He had a red car.' (nominative Pe with the referent's inclusive quantity)

(22) $\mathrm{Mu}-1$ (Pr) ol-i sõpr-u (Pe).

I-AD be.PST.3SG friend-PL.P

'I had (some) friends.' (partitive Pe with the referent's non-inclusive quantity)

The possessive construction expresses a possessive relation; clauses expressing predication or spatial location have been excluded. Also clauses expressing external possessors have been left out of the analysis:

(23) Õpetaja-1 on selle-ks (erilise-ks) koha-ks

teacher-AD be. 3 this-TRAN special-TRAN place-TRAN

paekarjäär.

limestone.quarry.N

'For the teacher the limestone quarry is this (special) place.' (a non-possessive clause with an external possessor)

The possessive construction usually has a human, sometimes also a concrete or abstract entity as the Pr. The Pe is usually a concrete or abstract entity. Elliptical clauses have been included if it is evident from the context that the clause is expressing a possessive relation:

(24) $\varnothing$

seiere-id pole $=$ gi.

(clock-AD) hand-PL.P be.NEG=CL

'Surprisingly, (the clock) does not have hands.'

Sometimes there is another obligatory NP in the possessive clause:

(25) $\mathrm{Mu}-1$ on su-lle üks palve.

I-AD be. 3 you-ALL one.N request.N

'I have a request for you.' (possessive clause with an obligatory allative NP)

Some possessive clauses can be very similar to existential clauses. However, the existential clause has a much freer choice of verbs and, unlike in the case of the typical possessive clause, its locative phrase is non-human. 


\section{Experiential construction $\boldsymbol{A L L}-\boldsymbol{V}-\boldsymbol{N} / \boldsymbol{P}-(X)$}

There are several experiential constructions in Estonian, some of them belonging to the marked basic clause type, and some to the unmarked clause. The experiential construction subtype under scrutiny here is the one with the allative experiencer (sometimes interchangeable with the adessive) and it is a representative of marked basic clauses. Previously the morphosyntactic properties of the Estonian causative emotion construction have been studied. That construction has a partitive experiencer (Lindström 2012).

The only obligatory components of the present construction are an allative NP with the experiencer meaning, ${ }^{11}$ a mental verb, a nominative NP with the stimulus meaning that, under certain circumstances, can rarely take the partitive. In the analysis I looked at examples with the following verbs: meeldima 'to be likeable', tunduma 'to seem', meelde jä̈̈ma 'to stay in memory', meelde tulema and meenuma 'to recall, come to mind'. The arguments whose subjecthood is being studied are both the experiencer (Exp) and the stimulus (St) (see examples 26-28). ${ }^{12}$

(26) Ta-lle (Exp) meeldi-b fotograafia (St). s/he-ALL be.likeable-3SG photography.N 'He likes photography.'

(27) $\mathrm{Mu}-1 \mathrm{le}(\mathrm{Exp})$ tundu-b see (St) sirge-na. I-ALL seem-3SG it.N straight-ESS 'It seems straight to me.'

(28) Ja muu-d (St) su-lle (Exp) meelde ei tule. and something.else-P.SG you-ALL in.mind NEG come 'And nothing else is coming to your mind.' (partitive stimulus in negation)

Hence, in this study, the experiential construction's arguments are defined on the basis of a verbal class argument structure. The predicate agrees with the stimulus if it is in the nominative. The stimulus can occur in the partitive under negation, and in this case there is no agreement on the verb. Semantically, Exp is a human and St can be a human or an entity with concrete, abstract or event meaning. In gen-

11 Often there is no clear difference in the use of the allative and the adessive (Erelt et al. 1993).

12 I have excluded from the analysis the experiencer clauses that bear a predicative relation:

Mu-lle on see ükskõik.

I-ALL be. 3 it.N all.the.same.N

'It is all the same for me' (experiential construction) 
eral, St is not volitional in the situation, and not actively or deliberately affecting the Exp. Sometimes there may be additional obligatory oblique NPs in the clause, for example the essive NP in 27.

A necessary precondition for determining an NP's degree of subjecthood in a clause is regarding it as a core argument. I regard both the Exp and the St as core arguments and not adjuncts of the construction (despite the fact the Exp is not in a grammatical case). They are usually obligatory in the clause (leaving aside ellipsis), they are semantically not circumstantial but necessary parts of the event, Exp also has a collocational relation with the verb (kellelegi meeldima 'to be likeable for someone'; compare: *eile meeldima 'to be likeable yesterday') (cf. Matthews 1981: 124-126). St should also be regarded an argument because it has subject-like case and agreement.

\section{Source-marking resultative construction $E L-V-N / P$}

Resultative clauses characterize the change of state of an entity. In this paper I will look at a subtype of resultative clauses: a sourcemarking resultative construction, described in Erelt (2005). Its obligatory parts are a typically topical NP depicting the entity in the initial state, the usually post-verbal NP depicting the resultant state and the predicate that agrees with the latter. Following Erelt, I call the first argument the source (So) and the second argument the goal (the term was presumably adopted due to its metaphoric similarity to the end of movement/transfer meaning; to distinguish it from the $\mathrm{G}$ argument of ditransitives I will abbreviate it $\mathrm{Gr}$, the goal of the resultative clause). The So argument is in the oblique case elative and Gr alternates between the nominative (affirmative clauses) and the partitive (negative clauses).

$\begin{array}{ll}\text { (29) Maria-st (So) sa-i } & \text { opetaja (Gr). } \\ \text { Maria-EL become-PST.3SG } & \text { teacher.N } \\ \text { 'Maria became a teacher.' } & \end{array}$

In general the $\mathrm{Gr}$ argument cannot take the partitive in affirmative clauses (Erelt and Metslang 2006: 261). Source-marking resultative clauses are rare in discourse, probably due to their specific argument coding and extremely narrow meaning.

So far we have seen that the typically clause-final NPs of the source-marking resultative, possessive and existential construction have many features in common (unlike the obliques, all of them are nominative-permitting and agreement-permitting arguments).

The constructions above are defined in a way that allows some significant variation in them. For example the existential construction 
allows the case alternation of e-NP, and even the occurrence of agreement can depend on it. ${ }^{13}$ At the same time the nominative and partitive e-NPs share many features too (word order, several behaviour constructions, the ban of zero-anaphora, etc.; see below). Therefore treating these variants together as one (higher level) construction is justified for the purposes of this study. An alternative view would be treating them as two separate constructions. ${ }^{14}$

\section{On the semantics of the subjects and subject-like arguments}

Helasvuo and Huumo (2010: 171-173) have studied the Finnish subject from the point of view of cognitive linguistics, largely on the basis of Langacker's work (e.g. 1987, 1991a, 1991b). Their suggestions on the arguments' and constructions' semantics help to analyze the Estonian data as well. The subject's function according to cognitive linguistics is to be the clause-level trajector (the most prominent participant of the process depicted by the clause; it relates in predication to one or more landmarks or other background participants). The subject is the beginning of the energy flow (e.g. in a situation depicted by a transitive clause from the agent to the patient) or of subjective conceptualization of the situation; it is the starting point of the clause (the starting element of some natural path, i.e. some cognitively natural ordering of the elements of a complex structure). Helasvuo and Huumo have shown that in Finnish most of the subjects correspond to these subject roles but the e-NPs do not (they discuss e-NP in a broad sense, including e.g. the similar NPs of the resultative and possessive clauses). This is one of the reasons why they suggest removing this argument from the subject category.

Estonian seems to be similar to Finnish in this respect: although the subjects of unmarked clauses prototypically serve as the trajector and also as the starting point of the energy flow or conceptualization, the nominative and partitive NPs of the existential, possessive and sourcemarking resultative clauses do not. Table 1 looks at various subjectlike arguments and is based on the constructions' definitions provided above and on the data of the balanced corpus of the Corpus of Written Estonian. It poses a rough hypothesis of the possible tendencies of whether the argument types are typically the starting points of the event's/process' or the conceptualization's energy flow. If a particular argument's value is the same as the highly transitive clause's subject's, I have given it 2 points, if it is clearly different I gave it 0

13 This is the case when the verb is not in the unmarked third person singular form and when the agreement is not lacking in the case of the plural partitive (see the subsection of the Existential construction above).

14 I thank Liina Lindström for pointing this interesting possibility out for me. 
points. If the argument shows a lower degree of subjecthood with respect to energy flow, I have given it 1 point (see above for the explanation of the abbreviations).

Table 1. The subject-like arguments as semantic starting points of energy flow.

\begin{tabular}{l|c|c|c|c|c|c|c|c|c|c} 
Criterion & A & S & d-S & Exp & St & Pr & Pe & So & Gr & e-NP \\
\hline Starting point (energy flow) & 2 & 1 & 0 & 1 & 1 & N/A & N/A & 2 & 0 & N/A
\end{tabular}

As the possessive sentences are typically stative, there is no energy flow from one entity to another. Therefore this criterion is not applicable to the arguments of the possessive clause (marked as N/A). In the data, the e-NPs also usually occur in stative sentences where there is no energy flow. ${ }^{15}$ The experiential constructions under scrutiny are often static too, see examples 26 and 27 above. However, often they also depict a dynamic situation with a change of state, for example:

(30) Olivia-le tul-i-d meelde vanaema sõna-d.

Olivia-ALL come-PST-3PL in.mind granny.G word-PL.N

'Olivia recalled Granny's words.' Lit. 'Granny's words came to Olivia's mind.'

In the initial state of the situation, Granny's words are not in Olivia's mind yet. In the resultant they have occurred to her. The starting point of the conceptualization is the St. Metaphorically, the stimulus enters the experiencer's mind. In other experiential clauses, also Exp can be the starting point of the energy flow.

The semantic properties that are likely to bring the Estonian e-NP closer to the object and distinguish it from the unmarked basic clause subject are the following:

- e-NP is meaning-wise not the conceptual starting point of the clause.

- e-NPs do not tend to encode discourse prominent referents (animate, definite, given). ${ }^{16}$

- As Vilkuna (1989) suggests about Finnish, e-NP demonstrates a high degree of semantic unity with the predicate verb "in terms of existence dependency and selectional restrictions". Vilkuna finds that in Finnish the verb - e-NP pair in the existential clauses can be

15 The dynamic existential clauses require a closer analysis from the point of view of semantic energy flow.

16 For example, out of 183 affirmative existential sentences in the author's data, only 17 e-NPs are definite and 102 denote inanimate concrete entities (see also Metslang to appear). 
analyzed as one information constituent that is formed as a result of incorporation of the non-individuated NP. ${ }^{17}$ Semantic bonding shows in the analogous uses of the existential NP and the object of the impersonal (Vilkuna 1989: 156-157, 195). ${ }^{18}$ The bonding is also reflected by the frequent lack of clear agreement between the e-NP and the verb which can be analyzed as an object property. The same properties are likely to hold in the case of the Pe and possibly also Gr argument.

In the next sections I will outline the subject criteria I use and analyze their applicability to the aforementioned argument types. I will start with discussing the coding properties and then proceed to the behavioural features.

\section{Analysis of the coding properties}

This section discusses five coding properties of subject-like arguments: case in affirmative clauses, case in negative clauses, agreement, zero-anaphora and word order of A, S, e-NP, Pr, Pe, Exp, St, So and $\mathrm{Gr}$ (see the explanations in section 4). As the A and S can be regarded as prototypical subjects, the focus of this and the following section is more on the subject-like arguments of marked clauses as they will be compared to A and S. I will start this section by presenting a summarizing table of the five subject-like coding properties and then proceed to discussing each of them separately. This section mainly relies on the findings of earlier studies and focuses on making the suggested properties comparable with the behavioural data in section 6. I will present some new (preliminary) statistical data about word order and zero anaphora.

17 This refers back to the previous point. Non-individuation is related to the non-humanness, quantitative and qualitative indefiniteness and abstractness of the e-NP (cf. Hopper and Thompson 1980: 253).

18 According to the Finnish tradition, Vilkuna calls the latter constituent object and the construction passive. In the context of Estonian, the analogy is between impersonal and existential clauses (see above in this section). 
Table 2 Coding properties studied in this analysis.

\begin{tabular}{|c|c|c|c|c|}
\hline No & $\begin{array}{l}\text { Subjecthood } \\
\text { criterion }\end{array}$ & $\begin{array}{l}\text { Obligatorin } \\
\text { ess of the } \\
\text { feature }\end{array}$ & Description of the criterion & Source \\
\hline 1 & $\begin{array}{l}\text { case in the } \\
\text { affirmative } \\
\text { clause }\end{array}$ & obligatory & $\begin{array}{l}\text { the closeness of argument's } \\
\text { case to the prototypical subject } \\
\text { case }\end{array}$ & $\begin{array}{l}\text { Erelt et al. } \\
1993\end{array}$ \\
\hline 2 & $\begin{array}{l}\text { case in the } \\
\text { negative } \\
\text { clause }\end{array}$ & obligatory & $\begin{array}{l}\text { the closeness of argument's } \\
\text { case to the prototypical subject } \\
\text { case in a neutral, non- } \\
\text { contrastive negative clause }\end{array}$ & $\begin{array}{l}\text { Erelt et al. } \\
1993\end{array}$ \\
\hline 3 & $\begin{array}{l}\text { zero- } \\
\text { anaphora }\end{array}$ & statistical & $\begin{array}{l}\text { prototypical, highly ranked } \\
\text { subjects tend to be dropped }\end{array}$ & $\begin{array}{l}\text { Lindström } \\
\text { et al. } 2008\end{array}$ \\
\hline 4 & agreement & obligatory & $\begin{array}{l}\text { the verb agrees with the } \\
\text { prototypical subject in person } \\
\text { and number }\end{array}$ & $\begin{array}{l}\text { Erelt et al. } \\
1993\end{array}$ \\
\hline 5 & word order & statistical & $\begin{array}{l}\text { prototypical, highly ranked } \\
\text { subjects tend to occur pre- } \\
\text { verbally }\end{array}$ & $\begin{array}{l}\text { Lindström } \\
2005 ; \\
\text { Huumo } \\
2002\end{array}$ \\
\hline
\end{tabular}

In this section, as well as in the next one, I rank the arguments, using a scoring system with three values. The arguments that are coded or behave similarly to the prototypical subject receive the highest ranking with respect to the particular criterion. The arguments receive the lowest ranking when they are coded or behave totally differently from the prototypical subject, when I could not find or think of (using my native speaker intuition) any examples of the argument's occurrence in the subjecthood test construction under scrutiny. The arguments received a medium ranking if they have properties both similar and different from the prototypical subjects. If an argument receives a medium ranking with respect to a behaviour test, it usually only has this subjecthood property to an extremely limited extent (there may be only few examples in the data sources and there may be a shift that occurs in the construction's main meaning or conceptualization towards the argument's volitionality or agentivity if used with the test construction) or only a subpart of this argument type behaves like a prototypical subject. If an argument gets the medium ranking with respect to some coding property, it can be coded both in a subject-like and non-subject like way. For the sake of ease of representation I marked the rankings with numerical values: the high ranking 
arguments are marked with a " 2 ", the medium ranking arguments are marked with a " 1 " while the low ranking arguments receive " 0 ".

This section will show that of the non-prototypical subject-like arguments, the St and d-S received the highest coding scores in the subjecthood continuum and are hence more subject-like than the other studied elements. Pr and So are the least subject-like in the set (see Table 3 at the end of this section).

As mentioned above, the case of the prototypical subjects (A and $\mathrm{S}$ ) is the nominative. As the nominative only serves as the object case in very restricted contexts (cf. the beginning of section 4) I regard the nominative case in affirmative clauses as a subjecthood property. From the point of view of case-marking, the subject-like arguments form three groups. Similarly to A and S, also d-S, St and Gr occur in the nominative. They receive the subjecthood score 2 (see Table 5 below). Pe and e-NP are coded less prototypically: like direct objects, they have the common option of nominative-partitive case alternation but at least they are still in a grammatical case. They get the medium score (1). The third group, the clause-initial arguments of marked clauses, Exp, Pr and So, are marked with oblique, locative cases. As these cases are primarily used in concrete locative contexts to mark adjuncts, I regard these arguments' marking as even less subject-like and give them a ranking of 0 .

In negation, prototypical subjects and $\mathrm{d}-\mathrm{S}$ retain their nominative marking and will therefore be assigned the value 2 . The marked basic clause clause-final arguments (St, Pe, Gr and e-NP) can just take the partitive or both the nominative and partitive. As the partitive is a grammatical case but not used in negation with the prototypical subjects, I regard the members of this second group positioning in the middle of the subjecthood continuum with respect to case in negation (ranking 1). The least subject-like coding in the negative clauses is the oblique case, therefore Exp, Pr and So receive a score of 0.

Agreement is a coding property that appears in affirmative clauses with prototypical subjects and does not appear with objects. ${ }^{19}$ Therefore agreement can be considered a clear subject property that can be used as diagnostics. Agreement takes place between the predicate verb and the nominative subject or subject-like argument. The verb does not agree with these subject-like arguments that are in the partitive. The arguments that consistently trigger agreement on the verb (A, S, $\mathrm{d}-\mathrm{S}, \mathrm{St}$ and $\mathrm{Gr}$ ) are given 2 points with respect to this criterion. ${ }^{20}$ The

19 See Torn-Leesik 2009: 85 for the limited set of exceptions to this rule: in the impersonal clauses with the nominative object is sometimes used with verbal agreement.

20 Although the verb is often in the default third person singular form in the experiential and source-marking resultative constructions, St and $\mathrm{Gr}$ received 2 points because there are 
arguments that can but not always do trigger agreement have been given 1 point in the agreement score (e-NP, Pe). The arguments that cannot trigger agreement receive 0 points (the oblique arguments $\mathrm{Pr}$, Exp and So).

Agreement, as well as case, are the two coding properties that play a role in signalling the privileged treatment of arguments in the syntactic behaviour constructions. Despite the fact that in general I have applied the method of taking all subjecthood criteria as equal with each other in this study (see section 3), there seem to be special cases where it may be useful to allow exceptions. Tael (1988b: 141) suggests that agreement is the clearest subjecthood criterion in Estonian. It is usually a clearer property than case, as objects can also be marked by the same case as prototypical subjects (the nominative) however the predicate verbs cannot agree with them. In some fuzzier cases of raising and control, it is only possible to use agreement as a decision-making basis about the subject-like treatment of arguments (see section 6). ${ }^{21}$ For example, in the following subject raising construction, agreement in number helps us to decide that it is the $\mathrm{Gr}$ argument and not the So that is raised and hence treated like the subject:

(31) (Nen-de hulgast eraldu-b järelkasv,) they-G.PL from.among part-3SG offspring.N kelle-st (So) või-vad kujune-da tippsportlase-d (Gr). who-SG.ELA may-3PL develop-INF top.sportsman-N.PL '(An offspring parts from them) from which may develop top sportsmen.' (subject raising, Gr)

(32) * ... kelle-st või-b kujune-da tippsportlase-d. who-SG.ELA may-3SG develop-INF top.sportsman-N.PL Intended: ...' from which top sportsmen may develop.'

There are also some test constructions where the argument's occurrence in the matrix clause object position is taken as a subjecthood property (subject-to-object raising, object control; see Table 6 in section 6). As the verb does not agree with the object in Estonian, agreement cannot be used in these constructions as an indicator of subjectlike treatment. I suggest that in these tests subjecthood is most clearly

plenty of examples of clear agreement (plural nomnative NP) and no examples of clear lack of agreement in affirmative clauses.

21 The agreement test has also been used to determine the raised argument in other languages, e.g. in the case of Finnish (Hakulinen 1983: 246). 
reflected by case (and not for example by word order as case rather depends on strict rules and word order is more flexible).

Estonian allows both the omission (lack) of the subject pronouns and the object pronouns that are known from the context, see (51) in section 6.1 (b). However, there is a strong tendency to omit the (first and second person) subjects of unmarked clauses, whereas the objects as well as the subject-like arguments of marked clauses tend to be overtly expressed. Lindström et al. (2008: 184-185) have shown on Estonian dialects that there is a range of factors influencing the lack of the first person subject pronoun in a clause, the most important ones of which are the referential distance from the previous mention, text structure, syntactic connection type between clauses and the presence of the agreement marker $-n$ on the verb.

Table 3 sketches some preliminary data on pronoun omission (zero anaphora) of some argument types in Estonian. I have analyzed randomly selected examples from the balanced sub-corpus of the Corpus of Written Estonian. The data includes the percentages of the finite clause argument omissions. The table does not include passive subjects, as zero-anaphora does not go with the function of promoting the object, the main feature of the passive clauses. I was unable to find examples with the ellipsis of any of the source-marking resultative construction arguments: in the case of the lack of one of the arguments, the sentence loses the characteristics of this construction.

Table 3. The occurrence of zero-anaphora among argument types.

\begin{tabular}{c|c|c|c} 
Argument & Zero-anaphora & N & Subjecthood score \\
\hline $\mathbf{A}$ & $39 \%$ & 130 & 2 \\
S & $30 \%$ & 130 & 2 \\
d-S & $4 \%$ & 150 & 0 \\
Pr & $6 \%$ & 300 & 0 \\
Pe & $4 \%$ & 300 & 0 \\
Exp & $28 \%$ & 300 & 2 \\
St & $5 \%$ & 300 & 0 \\
O & $2 \%$ & 100 & 0
\end{tabular}

As the table suggests, zero-anaphora is a property in Estonian that can statistically distinguish the prototypical subjects from objects. The table shows that whether an argument has subject-like coding with respect to this property depends on the construction type and topicality (zero-anaphora is permitted with the prototypically topical arguments 
of unmarked active clauses and experiential constructions). When comparing the arguments in the table, I have used a $95 \%$ confidence interval to test for a statistically significant difference between independent sample proportions. The frequencies of zero-anaphora usage of A, S and Exp are significantly different from all the other arguments. The zero-anaphora frequencies of Exp (28\%) and A (39\%) are significantly different at this confidence interval but the frequencies of Exp and S (30\%) are not. For the latter reason I evaluated Exp having this subjecthood property (score 2). In the next example, the experiential clause lacks both the Exp with the generic person referent and the St with a discourse-active referent (a referent that the speaker assumes being identifiable in the addressee's mind and in his focus of consciousness at a given moment in time; Lambrecht 1994):

(33)

$\begin{array}{llll}\text { (Unenäo-d } & \text { näita-vad } & \text { ammu-unusta-tud } & \text { sündmus-i,) } \\ \text { dream-N.PL } & \text { show-3PL long.ago.forget-IMPS.PST.PTC event-P.PL } \\ \text { sellepärast } \varnothing & \text { jää-vad-ki } \varnothing & \text { meelde. } \\ \text { therefore } & \text { (they.N) } & \text { stay-3PL-CL (one-PL-ALL) } & \text { in.mind }\end{array}$
'(The dreams show events that were forgotten long time ago,) that is why (they) stick in (one's) mind.' (Experiential clause)

As Estonian has partially free word order, the subject position criterion is not very reliable. Estonian word order primarily depends on the V2 rule (Huumo 2002: 502) and preverbal and postverbal subjects are nearly equally frequently represented in written data (Tael 1988a: 8). However, the neutral subject position is preverbal and postverbal subject position is often retraceable to emphasis and text-bound topic or to the use of e-NP (ibid.: 6-11). Prototypical subjects, especially the semantically and discourse-wise most highly ranked ones, are preverbal in Estonian (cf. Lindström 2002: 100-101). Huumo (2002) has shown that in his corpus of Estonian literary texts there is a strong tendency that animate, given and pronominal subjects are preverbal (these tendencies are even stronger in the spoken language; Lindström 2005). Metslang (to appear) shows that the majority of Estonian A and S arguments are discourse-active, they are pronominally marked and have speech act participant or person reference. On the basis of the existent word order studies on Estonian (Lindström 2004: 44, 48; Huumo 1993: 114; Metslang, to appear; Remmel 1963: 258-261), I conclude that it is very likely that the more frequent position of the direct object is postverbal. Therefore I have included preverbal position in the set of subjecthood properties. Table 4 shows the results of my analysis on the word order properties of different argument types. The data is drawn from the balanced sub-corpus of the 
Corpus of Literary Estonian; the elliptical examples have not been included here.

Table 4. The arguments' occurrence in the preverbal position.

\begin{tabular}{c|c|c|c} 
Argument & Preverbal & N & Subjecthood score \\
\hline $\mathbf{A}$ & $73 \%$ & 100 & 2 \\
S & $74 \%$ & 100 & 2 \\
d-S & $73 \%$ & 150 & 2 \\
e-NP & $10 \%$ & 145 & 0 \\
Pr & $84 \%$ & 282 & 2 \\
Pe & $18 \%$ & 289 & 0 \\
Exp & $88 \%$ & 216 & 2 \\
St & $28 \%$ & 285 & 1 \\
So & $72 \%$ & 128 & 2 \\
Gr & $15 \%$ & 128 & 0 \\
O & $9 \%$ & 100 & 0
\end{tabular}

When comparing the arguments in the table, I have again used a $95 \%$ confidence interval to test for a statistically significant difference between independent sample proportions. At this confidence interval, there is a significant difference between the unmarked clause subjects on the one hand and all nominative-permitting subject-like arguments (e-NP, Pe, St, Gr) and $\mathrm{O}$ on the other hand. There is no significant statistical difference between the frequencies of preverbal occurrence of A, S, d-S and So. There is a significant difference between the preverbal occurrence frequencies of the unmarked subjects and those of Exp and Pr: the latter arguments occur preverbally more often than the prototypical subjects. However, as I am regarding preverbal position as a subjecthood property, I rate the Exp and Pr highly in their subjecthood score with respect to word order (2 points). St and Pe have a statistically lower preverbal position frequency than A. There is a continuum of frequency values between the preverbal $\mathrm{St}$ (28\% preverbal) and O (only 9\% preverbal). Although the extreme ends of this continuum - the St and the $\mathrm{O}$ - are statistically different from each other, the arguments between them are not. Nevertheless, I have distinguished the higher ranked one ( $\mathrm{St}-1$ point) from the lower ranked ones (e-NP, $\mathrm{Pe}, \mathrm{Gr}$ and $\mathrm{O}-0$ points). ${ }^{22}$

22 Lindstöm has analysed word order in another experiential construction: experiencer object construction and found remarkable word order variation there (2012: 41). 
Table 5 shows the distribution of coding properties with the arguments under consideration.

Table 5. Distribution of the coding properties $(2-$ the argument has the same value as the prototypical subject with respect to this property; 1 - the argument shows a lower degree of subjecthood with respect to this property; 0 - the argument does not have this subjecthood property).

\begin{tabular}{l|c|c|c|c|c|c|c|c|c|c} 
Criterion & A/S & d-S & St & Gr & Pe & e-NP & Exp & Pr & So & Total \\
\hline $\begin{array}{l}\text { Word order } \\
\text { Case in the } \\
\text { affirmative } \\
\text { clause }\end{array}$ & 2 & 2 & 1 & 0 & 0 & 0 & 2 & 2 & 2 & 11 \\
\hline Agreement & 2 & 2 & 2 & 2 & 1 & 1 & 0 & 0 & 0 & 10 \\
\hline $\begin{array}{l}\text { Case in the } \\
\text { negative clause }\end{array}$ & 2 & 2 & 1 & 1 & 1 & 1 & 0 & 0 & 0 & 8 \\
\hline Zero-anaphora & 2 & 0 & 0 & 0 & 0 & 0 & 1 & 0 & 0 & 3 \\
\hline Total & $\mathbf{1 0}$ & $\mathbf{8}$ & $\mathbf{6}$ & $\mathbf{5}$ & $\mathbf{3}$ & $\mathbf{3}$ & $\mathbf{3}$ & $\mathbf{2}$ & $\mathbf{2}$ &
\end{tabular}

The table shows that the distributions of affirmative case and agreement properties coincide, and that $\mathrm{A}, \mathrm{S}$ and d-S score higher in subject-like coding than the marked clauses' subject-like arguments. The nominative-permitting marked-clause arguments get higher coding scores than the oblique ones. Prototypical subjects share their preverbal position with the oblique arguments, zero-anaphora with many Exp-s and the nominative case with many e-NP-s, Pe, St and Gr-arguments. Hence the data supports the view that Helasvuo (2001: 103) has expressed on Finnish that "coding does not clearly distinguish the subject as a distinct grammatical role".

\section{Analysis of behavioural properties}

When determining the behavioural criteria suitable for Estonian I first made a list of the properties suggested for prototypical subjects both in typological literature (e.g. Barðdal 2006; Bickel 2004; Kroeger 2004; Van Valin 2005) and in Estonian and Finnish linguistics (mainly Erelt et al. 1993; Hakulinen et al. 2004; Hiietam 2003). I then judged their suitability as subjecthood tests on the basis of corpus data, discarding the properties that did not characterise A or S as well 
as the ones that were simultaneously characteristic of objects or adjuncts, too.

In this section I will outline the 11 behavioural subjecthood criteria that I found suitable for Estonian and show their distributions among the subject-like arguments. In the following, 9 interclausal constructions will be evaluated: 2 raising constructions (section 6.1), 4 subject control and 3 object control constructions (section 6.2; of these 2 control constructions of participial relativization will be discussed together). In addition, the antecedence of reflexive and possessive pronouns and occurrence in the impersonal construction will also be looked at (section 6.3). (See the summary of all these criteria in Table 6 below.) Section 6.4 will give an overview of the potential tests that I regard as unsuitable for measuring subjecthood in Estonian. Some of these criteria represent very closely related subject properties (see section 7). To introduce the tests, I will first give a short summary of relevant notions in this discussion.

Raising and control constructions consist of the matrix clause and the lower non-finite clause. They tend to give one of its participating arguments a special prominence. In the case of many accusative languages, this privileged treatment is reserved for subjects, whereas objects and adjuncts are excluded from it. For example:

(34) Ta tundu-b maga-vat.

s/he.N seem-3SG sleep-INF

'He seems to be sleeping.' (subject-to-subject raising)

*Õun tundu-b ta söövat.

apple.N seem-3SG s/he.N eat-INF

Intended: 'It seems that he is eating an apple.' (impossibility of objectto-subject raising)

(35) Ma luba-si-n harjuta-da.

I.N promise-PST-1SG practice-INF

'I promised to practice.' (subject control with a subject contollee)

(36) *Ma palu-si-n te-da $\varnothing_{\mathrm{i}} \quad$ kaits-ta.

I.N ask-PST-1SG s/he.P (him/herself) write-INF

Intended: 'I asked him to protect himself.' (impossibility of (obligatory) object control with an object controllee)

Both construction types obligatorily require the argument of the complement predicate to be shared with ('controlled by' or 'raised to') an argument of the matrix predicate (Bickel 2004: 94). This shared argument of the lower clause is called the pivot or controllee. The 
term 'pivot' is used for specific sets of arguments (either S and A or S and $\mathrm{O}$ arguments) "that are targeted by a syntactic construction as being referentially controlled, zeroed, relati[vi]zed, etc.“ (Bickel 2004: 106). Raising differs from control in that if in the case of control, there are both the controller and the (obligatorily deleted coreferent) pivot argument then in raising constructions there is only the pivot (Van Valin 2005: 96). Controllers are the elements that trigger verb agreement, antecede a reflexive, or supply the interpretation for a missing argument in an adjacent unit (Van Valin 2005: 95). In the case of raising, the complement's pivot argument is also the matrix S/A or O argument. The argument that has access to the pivot position is defined, indexed by the matrix verb's agreement (Bickel 2004). Raising constructions can be defined by morphological marking, semantics or construction type (cf. Bickel 2004: 97; Van Valin 2005: 101). In many languages, pivothood is reserved for subjects.

The following tables characterize the properties that I believe are best suited for describing Estonian subjects. The non-finite forms, the predicates of lower clauses appear in are the supine, the $d a$-infinitive, the vat-infinitive, the converbs (-des, -mata, -nud, -tud forms), and the participles (the active present participle $(-v)$, the active past participle (-nud), the passive present participle (-tav) and the passive past participle (-tud)).

Table 6. Subjecthood properties in Estonian: interclausal constructions.

\begin{tabular}{l|l|l|l}
$\begin{array}{l}\text { Subjecthood } \\
\text { criterion }\end{array}$ & $\begin{array}{l}\text { Obligatori- } \\
\text { ness of the } \\
\text { feature }\end{array}$ & Description & Example \\
\hline $\begin{array}{l}\text { a) subject-to- } \\
\text { subject raising }\end{array}$ & Obligatory & $\begin{array}{l}\text { The subject of the } \\
\text { lower clause must } \\
\text { occur in the matrix } \\
\text { verb's subject } \\
\text { position }\end{array}$ & $\begin{array}{l}\text { Ta tundu-b maga-vat. [s/he.N } \\
\text { seem-3SG sleep-INF] 'He } \\
\text { seems to be sleeping.' }\end{array}$ \\
\hline $\begin{array}{l}\text { b) subject-to- } \\
\text { object raising }\end{array}$ & Obligatory & $\begin{array}{l}\text { The subject of the } \\
\text { lower clause must } \\
\text { occur in the matrix } \\
\text { verb's object } \\
\text { position }\end{array}$ & $\begin{array}{l}\text { Ma kujutle-n te-da tule-mas. } \\
\text { [I.N imagine-1SG s/he-P } \\
\text { come-SUP.IN] 'I imagine } \\
\text { him coming.' }\end{array}$ \\
\hline
\end{tabular}




\begin{tabular}{|c|c|c|c|}
\hline $\begin{array}{l}\text { Subjecthood } \\
\text { criterion }\end{array}$ & $\begin{array}{l}\text { Obligatori- } \\
\text { ness of the } \\
\text { feature }\end{array}$ & Description & Example \\
\hline $\begin{array}{l}\text { c) pivot of a } \\
\text { subject control } \\
\text { construction } \\
\text { (taking } d a- \\
\text { infinitive) }\end{array}$ & Obligatory & $\begin{array}{l}\text { The subject of the } \\
\text { lower clause is the } \\
\text { controllee of the } \\
\text { coreferent matrix } \\
\text { subject and must be } \\
\text { deleted }\end{array}$ & $\begin{array}{l}\text { Ma luba-si-n } \emptyset \text { harjuta-da. } \\
\text { [I.N promise-PST-1SG (I.N) } \\
\text { practice-INF] 'I promised to } \\
\text { practice.' }\end{array}$ \\
\hline $\begin{array}{l}\text { d) pivot of a } \\
\text { subject control } \\
\text { construction } \\
\text { (taking supine) }\end{array}$ & Obligatory & $\begin{array}{l}\text { The subject of the } \\
\text { lower clause is the } \\
\text { controllee of the } \\
\text { coreferent matrix } \\
\text { subject and must be } \\
\text { deleted }\end{array}$ & $\begin{array}{l}\text { Ma lähe-n } \emptyset \text { õppi-ma. [I go- } \\
\text { 1SG (I.N) study-SUP] 'I will } \\
\text { go to study.' }\end{array}$ \\
\hline $\begin{array}{l}\text { e) pivot of a } \\
\text { subject control } \\
\text { construction } \\
\text { (taking con- } \\
\text { verbs) }\end{array}$ & Obligatory & $\begin{array}{l}\text { The subject of the } \\
\text { lower clause is the } \\
\text { controllee of the } \\
\text { coreferent matrix } \\
\text { subject and must be } \\
\text { deleted }\end{array}$ & $\begin{array}{l}\text { Ta kuula-s } \varnothing \text { vaiki-des. } \\
\text { [s/he.N listen-PST.3SG } \\
\text { (s/he.N) be.silent-CONV] } \\
\text { 'He was listening silently.' } \\
\text { ('... being silent') }\end{array}$ \\
\hline $\begin{array}{l}\text { f) relativization } \\
\text { (pivot of a sub- } \\
\text { ject or object } \\
\text { control construc- } \\
\text { tion taking } \\
\text { participles) }\end{array}$ & Obligatory & $\begin{array}{l}\text { The subject of the } \\
\text { lower clause is the } \\
\text { controllee of the } \\
\text { coreferent matrix } \\
\text { subject or object } \\
\text { and must be deleted }\end{array}$ & $\begin{array}{l}\text { Liftis sõitsid } \emptyset \text { vene keelt } \\
\text { rääki-va-d mehe-d. [in } \\
\text { elevator went (men) Russian } \\
\text { language speak-PTC-PL } \\
\text { man-PL] 'There were } \\
\text { Russian speaking men going } \\
\text { up in the elevator.' ('...going } \\
\text { in the elevator') } \\
\text { Vaata-si-n Ø rohus roni-va-t } \\
\text { mesilas-t. [watch-PST-1SG } \\
\text { (bee.N) in grass climb-PTC-P } \\
\text { bee-P] 'I was watching the } \\
\text { bee climbing in the grass.' }\end{array}$ \\
\hline $\begin{array}{l}\text { g) pivot of an } \\
\text { object control } \\
\text { construction } \\
\text { (taking } d a- \\
\text { infinitive) }\end{array}$ & Obligatory & $\begin{array}{l}\text { The subject of the } \\
\text { lower clause is the } \\
\text { controllee of the } \\
\text { coreferent matrix } \\
\text { object and must be } \\
\text { deleted }\end{array}$ & $\begin{array}{l}\text { Ma käski-si-n te-da } \varnothing \text { lahku- } \\
\text { da. [I order-PST-3SG s/he-P } \\
\text { (s/he.N) leave-INF] 'I told } \\
\text { him to leave.' }\end{array}$ \\
\hline
\end{tabular}




\begin{tabular}{l|l|l|l}
$\begin{array}{l}\text { Subjecthood } \\
\text { criterion }\end{array}$ & $\begin{array}{l}\text { Obligatori- } \\
\text { ness of the } \\
\text { feature }\end{array}$ & Description & Example \\
\hline $\begin{array}{l}\text { h) pivot of an } \\
\text { object control } \\
\text { construction } \\
\text { (taking supine) }\end{array}$ & Obligatory & $\begin{array}{l}\text { The subject of the } \\
\text { lower clause is the } \\
\text { controllee of the } \\
\text { coreferent matrix } \\
\text { object and must be } \\
\text { deleted }\end{array}$ & $\begin{array}{l}\text { Ma saada-n lapse } \boldsymbol{\emptyset} \text { mängi- } \\
\text { ma. [I send-1SG child.G } \\
\text { (child.N) play-SUP] 'I will } \\
\text { send the child to play.' }\end{array}$ \\
\hline
\end{tabular}

Table 7. Intraclausal subjecthood properties in Estonian.

\begin{tabular}{l|l|l|l}
$\begin{array}{l}\text { Subjecthood } \\
\text { criterion }\end{array}$ & $\begin{array}{l}\text { Obligatorin } \\
\text { ess of the } \\
\text { feature }\end{array}$ & Description & Example \\
\hline $\begin{array}{l}\text { i) reflexive } \\
\text { pronoun binding }\end{array}$ & Obligatory & $\begin{array}{l}\text { Reflexive anaphora } \\
\text { of the argument } \\
\text { must be marked by } \\
\text { a reflexive pronoun }\end{array}$ & $\begin{array}{l}\text { Ma ost-si-n korteri enda-le. } \\
\text { [I.N buy-PST-1SG flat.G } \\
\text { (my)self-ALL] 'I bought the } \\
\text { flat for myself.' }\end{array}$ \\
\hline $\begin{array}{l}\text { j) possessive } \\
\text { pronoun binding }\end{array}$ & Obligatory & $\begin{array}{l}\text { Possessive } \\
\text { anaphora of the } \\
\text { argument must be } \\
\text { marked by a } \\
\text { possessive pronoun }\end{array}$ & $\begin{array}{l}\text { Ta kirjelda-s oma avastus-t. } \\
\text { [he.N describe-PST.3SG } \\
\text { own.G discovery-P] 'He was } \\
\text { describing his discovery.' }\end{array}$ \\
\hline k) impersonal & Possible and & $\begin{array}{l}\text { The construction } \\
\text { can be transformed } \\
\text { into an impersonal } \\
\text { construction and } \\
\text { the argument must } \\
\text { be deleted or } \\
\text { demoted then }\end{array}$ & $\begin{array}{l}\text { Juhataja nimetata-kse } \\
\text { nonukogu poolt. [chairman.N } \\
\text { appoint-IMPS board.G by] } \\
\text { 'The chairman will be } \\
\text { appointed by the board.' }\end{array}$ \\
\hline
\end{tabular}

When evaluating the argument types' subjecthood across the behavioural criteria, I use the same three value marking system ("2", "1" and "0" points) as in the previous sections (see the description at the beginning of section 5). In this analysis, I am interested in the macro level: whether any representatives of a particular argument type can appear in the test constructions under scrutiny and not in the subdivisions within argument types. 


\subsection{Raising}

\section{(a) Subject raising}

Subject-to-subject raising, or simply subject raising, is a construction type where the matrix subject position is filled by the complement's pivot and there is no controller argument present in the construction. The subject semantically belongs to the lower predicate's argument structure. This paper uses a broad, construction-based definition of raising. Therefore, for determining the degree of subjecthood, only these conditions apply. Whether the construction involves a raising transformation is not under discussion here. Neither do the test constructions have to be identical in every way. For example, some Estonian verbs participating as matrix verbs in test (a) take the vat-infinitive as a complement whereas others take the $d a$-infinitive or supine. The verbs that typically participate in the test (a) constructions tend to be light: näima, paistma and tunduma 'to seem', tõotama 'to promise' and võima 'may', tavatsema 'to do something habitually', etc. Therefore raising is sometimes called light verb complementation (cf. Bickel 2004). In Estonian unmarked clauses it is agreement that indicates the raised subject. Therefore I also take agreement to be an indicator of the privileged treatment of marked clause arguments.

The corpus contains numerous examples of all the construction types under scrutiny in subject raising constructions.

(37) Ta huule-d (A) näi-sid varja-vat mingi-t saladus-t. she.G lip-N.PL seem-PST.3PL hide-INF some-P secret-P 'Her lips seemed to be hiding some secret.' (A)

(38) Poisi-ga paista-b asi (S) küll viltu kisku-vat. boy-COM seem-3SG thing. $\mathrm{N}$ indeed wrong go-INF

'Things seem to be going wrong with the boy.' ( $\mathrm{S}$ with an undergoer meaning)

(39) Anekdoodi-d(d-S) tundu-sid elu-st võe-tud ole-vat. joke-N.PL seem-PST3PL life-EL take-IMPS.PST.PTC be-INF 'The jokes seemed to be taken from (real) life.' (d-S)

Of subject-like arguments, it is the typically non-topical, nominative arguments that I regard as raised (nominative e-NP, Pe, St and $\mathrm{Gr})$.

(40) Esialgu tundu-sid viimase-1 poole-1 ole-vat kõik initially seem-PST.3SG last-AD side-AD be-INF all 
eelise-d (Pe).

advantage-N.PL

'Initially the latter side seemed to have all the advantages.' (Pe)

(41) Ema ja poja vahel paista-vad valitse-vat oma-d mother.N and son.N between seem-3PL rule-INF certain-N.PL mängureegli-d.

game.rule-N.PL

'There seem to be certain rules of the game between the mother and son.' (e-NP)

Ilusa-d asja-d (St) tundu-vad ta-lle meeldi-vat. nice-N.PL thing-N.PL seem-3PL s/he-ALL be.likeable-INF

'He seems to like nice things.' (Google, $\mathrm{St}$ )

(42)

Eeloleva-st üldlaulupeo-st tõota-b tull-a suur
coming-EL general.singing.festival promise-3SG come-INF big.N sündmus.

event.N

'The coming general singing festival promises to be (become) a big event.' (Gr)

If Pe occurs in the partitive, the verb does not agree with it and in this case it is hard to decide which argument is raised, the Pe or Pr. There are arguments in favour of both analyzes.

$$
\begin{aligned}
& \text { Kui teie par-ima-1 sõbra-l tundu-b ole-vat } \\
& \text { if you.G best-SUP-AD friend-AD seem-3SG be-INF } \\
& \text { teie ees saladus-i }(\mathrm{Pe}) \text {... } \\
& \text { you.G in.front.of secret-PL.P }
\end{aligned}
$$

'If your best friend seems to have secrets in front of you ...' (Pe, lack of agreement)

If we look at privileged treatment from the point of view of case, then we can regard the partitive Pe as raised, as it bears a grammatical case. If we look at the construction from the point of view of word order, we can regard the Pr to be raised as it is in the preverbal position. As I have selected agreement as the criterion for determining privileged syntactic arguments in test (a) constructions and the subjecthood treatment of Pe is only clear in the case of nominative arguments, Pe is given 1 point in the subjecthood ranking. Such a question does not arise in the case of existential, experiential and sourcemarking resultative constructions. The existential clause only contains one argument and I regard it as raised even when it is in the partitive. I 
gave e-NP 2 points on the subjecthood score. St and Gr do not usually occur in the partitive in affirmative clauses and therefore the predicate verb agrees with them. They are also given 2 points. If the raising clause is negative (i.e. the finite verb lacks agreement even in the case of the prototypical subject), I regard the e-NP, Pe, St and Gr argument as raised by the analogy with affirmative clauses.

To conclude this subsection, I will provide some examples that seem to be a borderline case between subject-to-subject raising and subject control (see section 6.2 (d)). They involve light verbs with the meaning 'to tend to, to trend' (kalduma, kippuma, tükkima) that take a supine complement and are also compatible with the marked clause constructions. For example:

(44) Nei-st kipu-vad edaspidise-s elu-s saa-ma ekstsessi-d(Gr). they-EL tend-3PL later-IN life-IN become-INF excess-N.PL 'In later life they tend to become excesses.' (Gr)

I discuss these constructions under raising and not control as usually the pivot cannot be regarded as an argument of the matrix verb. Example 44 could be paraphrased as follows:

(45)

Kipu-b ole-ma nii, et ne-i-st
tend-3SG be-INF so that they-PL-EL
edaspidise-s ecome-3PL
later-IN lif ekstsessi-d.
'It tends to be so that they become excesses in later life.'

The corpus also contains examples with d-S, e-NP, Pe and St.

(46) Enamus sadula-i-d (d-S) kipu-b ole-ma teh-tud most.N saddle-PL-P tend-3SG be-INF do-PST.PASS.PTC "tavalis-te" ratturi-te jaoks. ordinary-PL.G cyclist-PL.G for 'Most saddles tend to be made for 'ordinary' cyclists. (d-S)

(47) Minu suure-s töökoti-s tüki-b ole-ma üsna suur I.G big-IN work.bag-IN tend-3SG be-INF quite big.N segadus (e-NP). mess.N 'In my big work bag there tends to be quite a big mess.' (Google, e-NP) 
(48) Sellis-te-1 rahaandmis-te-1 tüki-b ole-ma nõue (Pe), such-PL-AD grant-PL-AD tend-3SG be-INF requirement.N.SG (et asi pea-b ole-ma Euroopa firma käest that entity.N must-3SG be-INF Europe.G company.G from oste-tud.) buy-PST.PASS.PTC

'Such grants tend to have the requirement (that the thing has to be bought from a European company.)' (Google, Pe)

(49)

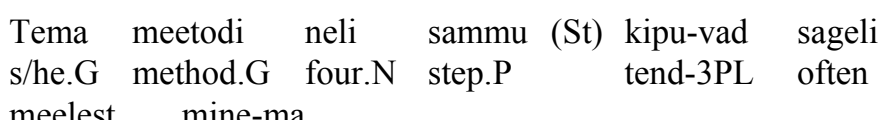
from.mind go-INF

'(I) often tend to forget the four steps of his method.' Lit. 'The four steps of his method often tend to leave from mind.' (St)

The original meaning of kippuma and tükkima is 'to strongly want to go, to forcefully want/insist on doing something' but it has usually bleached in these uses, especially in the case of kippuma. The original meaning has preserved better in the following example where the Exp is conceptualized as being an undergoer of the more active St:

(50)

$\begin{array}{lllll}\text { Paraku } & \text { kipu-b } & \varnothing & \text { kohe } & \text { järgmise-na } \\ \text { unfortunately } & \text { want-3SG } & \text { (I-ALL) } & \text { right.away } & \text { next-ESS } \\ \text { meelde tule-ma } & \text { põlisteutoonlik } & \text { maitselagedus. } \\ \text { into.mind come-INF } & \text { indigeneous.Teutonic } & \text { tawdriness.N }\end{array}$

'Unfortunately, the next thing that fires into (my) mind right away is the indigenous Teutonic tawdriness.' (St)

The occurrence of raising constructions in the data is summarized in Table 8 .

Table 8. Test (a): The occurrence of different argument types in subject raising constructions.

\begin{tabular}{l|c|c|c|c|c|c|c|c|c|c} 
Criterion & A & S & d-S & Exp & St & Pr & Pe & So & Gr & e-NP \\
\hline Subject raising & 2 & 2 & 2 & 0 & 2 & 0 & 1 & 0 & 2 & 2
\end{tabular}

To sum up, the pivot of the subject raising construction in Estonian is defined by morphological marking but not by e.g. semantics (compare Bickel 2004: 94, 95; Van Valin 2005: 101). All the nominativepermitting and agreement-permitting argument types can be raised while the oblique NPs cannot. 


\section{(b) Object raising}

Subject-to-object raising, or simply object raising, is a construction type where the complement's pivot occurs as the matrix $\mathrm{O}$ argument. The typical matrix predicates of the test (b) construction are arvama 'to think', tundma 'to feel', lubama 'to promise' that require an object in these interclausal constructions. When deciding which argument of a two argument lower clause (the transitive, experiential, possessive and resultative construction) is the pivot and therefore more subjectlike, I used two criteria:

- the argument is in an object case (the partitive, genitive or nominative);

- if there are more than two elements in the object case in the clause, the object of the lower clause non-finite predicate cannot be the pivot.

Naturally, agreement cannot be used as a criterion here, as predicates do not agree with objects in Estonian. For example:

(51) Arv
Arva-si-n
enda-1 õiguse (Pe) ole-vat.
think-PST-3SG self-AD right.G.SG be-INF
'I thought I was right.' Lit. 'I thought on myself being right.' (Pe)

We have two pivot candidates in this lower clause (the Pr endal and the Pe oiguse). The finite counterpart of the 51 lower clause would be:

(52) $\mathrm{Mu}-1$ on õigus.

I-AD be. 3 right.N.SG

'I am right.'

The case of the Pe argument can change from the nominative to the genitive with object raising. As the direct object is the only core grammatical relation that can be in the genitive in Estonian, I regard this as supporting evidence for the view that it is the object case argument that is the pivot in the object raising construction. Another example of object raising is with a transitive lower clause.

$$
\begin{aligned}
& \text { Mi-da sa arva-d } \quad \text { min-d (A) seal üleval tege-vat? } \\
& \text { what-P you.N think-2SG I-P there up do-INF } \\
& \text { 'What do you think of me doing up there?' (A) }
\end{aligned}
$$

Here both mida and mind are in the object case (the partitive). In order to decide which one is the pivot, we need to look at the lower 
clause elements. The finite counterpart of the 53 lower clause would be:

(54) Mi-da ma seal üleval tee-n?

what-P I.N there up do-1SG

'What am I doing up there?'

Here mida is the object while $m a$ is the subject. As the object of the lower clause cannot be the pivot, we can conclude that the pivot of 53 is mind 'me'.

In the case of intransitive clauses, existentials and passives, the pivot is the sole argument of the lower clause. For example:

(55) Tema asukoha, kelle (d-S) sa arva-sid ole-vat kindlalt he-G location.G who.G you.N think-PST.2.SG be-INF safely peide-tud, (and-is mu-lle tead-a Legault.) hide-PASS.PST.PTC give-PST.3SG I-ALL know-INF Legault.N '(It was Legault who let me know of his location,) i.e. of the one who you thought to be safely hidden.' Lit. 'His location who you thought to be safely hidden (let me know Legault).' (d-S)

(56) Just seal arva-takse ole-vat maailma ilusa-ima-d exactly there think-IMPS be-INF world.G beautiful-SUP-N.PL korallrifi-d (e-NP). coral.reef-N.PL

'The world's most beautiful coral reefs are thought to be exactly there.' Lit. 'Exactly there are thought being the world's most beautiful coral reefs.' (e-NP)

Erelt et al. (1993: 249-250) suggest that in the case of what is called object raising here, the case of the raised argument depends on the following factors:

- the argument in the matrix object position can take any object case (the partitive, genitive or nominative) in most lower clause construction types, depending on the requirements of the situation and the matrix verb, see (55) for the genitive, (56) for the nominative and (57) for the partitive.

- if the lower clause is a copula clause (belonging to the group of intransitive constructions in this analysis) or a source-marking resultative construction, the argument appears in the genitive singular or nominative plural (some internet examples show de- 
viances from the standard variety, see examples (58) for the partitive and (59) for the nominative singular). ${ }^{23}$

(57) $\mathrm{Ta}$ arva-b se-da (St) oma leivaisa-le meeldi-vat.

he.N think-3SG this-P.SG own.G employer-ALL be.likeable-INF 'He thinks this to be likeable to his employer.' (St)

(58) Kutsika-st luba-ti sirgu-vat võimsa-t ihukaitsja-t (Gr). puppy-EL promise-IMPS.PST grow-INF strong-P body.guard-P 'It was promised (to us) that the puppy would grow into a strong body guard.' Lit. 'From the puppy was promised growing a strong body guard.' (Gr)

(59) Välismaine ajakirjandus arva-b selle-st tule-vat väga foreign.N press.N think-3SG this-EL come-INF very suure ülekaalu-ga parim tsikkel $(\mathrm{Gr}), \mathrm{mis}$ saadaval on big.G majority-COM best. $\mathrm{N}$ motorcycle.N that. $\mathrm{N}$ available be. 3 'With a very big majority, the foreign press thinks this will become the best motorcycle available.' Lit. 'The foreign press thinks from this becoming, with a very big majority, the best motorcycle that is available.' (Gr)

The next example is of a lower clause $\mathrm{S}$ occurring in the matrix impersonal object position.

(60) Liisu (S) arva-ti juhusliku tulesurma ohvri-ks

Liisu.N think-PST.IMPS random.G fire.death.G victim-TR

lange-nud ole-vat.

fall-PST.PTC be-INF

'Liisu was thought to have become a victim of a random house fire.' (S with undergoer semantics)

Adding on to the case properties suggested above, in the case of impersonalization of object raising constructions, the raised object's case is restricted in the typical way to impersonals: the total object can only take the nominative and not the genitive (see the subsection on the Passive construction in section 4).

23 However, these perhaps overly complex example sentences of the non-genitive Gr argument in object raising may have caused some processing difficulty for the speaker, as they almost feel non-grammatical to the author's native-speaker intuition. Erelt et al. (1993) add the possessive clause to this group. However, the corpus contains possessive clauses whose raised Pe appears in all three grammatical cases. 
(61) Mul arva-ti õigus /*õiguse (Pe) ole-vat.

I-AD think- PST.IMPS right.N.SG / right.G.SG be-INF

'I thought I was right.' Lit. 'I thought on myself being right.' (Pe)

This supports the analysis that in example (51) the raised argument is specifically the Pe and not the Pr and that (60) in the lower subject (Liisu) is raised to the matrix clause. The raised partitive object retains its partitive in impersonalization, see example (58).

The corpus contains examples of all of the studied construction types. The arguments that can be frequently found as pivots of object control are A, S, d-S and Pe (2 points). I was able to find just a few examples with St, Gr and e-NP in the pivot position (1 point) and no examples with Exp, Pr and So (0 points). Table 9 summarizes the subjecthood measures of the studied arguments.

Table 9. Test (b): The occurrence of different argument types in object raising constructions.

\begin{tabular}{l|c|c|c|c|c|c|c|c|c|c} 
Criterion & A & S & d-S & Exp & St & Pr & Pe & So & Gr & e-NP \\
\hline Object raising & 2 & 2 & 2 & 0 & 1 & 0 & 2 & 0 & 1 & 1
\end{tabular}

As we can see again, the unmarked basic clause subjects and the nominative-permitting arguments pass the object-raising test, but the oblique arguments do not. Therefore, in this treatment, object raising also has a coding-based preference to its pivot, allowing only nominative-permitting arguments in the raised object position. The results could be different if the pivot of object control was defined in a different way, e.g. by being indicated by word order. However, as explained above, I find case a more reliable criterion.

\subsection{Control}

In this section I study the pivot (controllee) properties of four types of subject control constructions and three types of object control constructions. The occurrence as a controller in control constructions is not regarded here as an Estonian subjecthood property. As regards Icelandic, Barðdal (2006: 86) has suggested that the occurrence of different constructions in various control environments may depend on the semantics of the matrix and complement structure. In Estonian, topicality, coding and, as suggested in this paper, construction type (whether the argument belongs to unmarked or marked basic clause) are the major influence on the arguments' behavioural properties. Semantics plays a minor role in determining which arguments pass the 
subjecthood tests in Estonian. All tests can be passed by referents with the undergoer meaning. Although reflexivization and impersonalization (see below) are reserved for animate referents, all other behaviour tests can be passed by inanimates. In some tests, semantics may play a role on the micro-level where occurrence in the construction brings about a volitionality interpretation of inanimate referents (cf. Table 21 in section 7).

Tables 10 and 11 give some examples of the particular semantic uses for each control construction. Their purpose is to show that in most cases, the choice of verbs in the matrix and lower clause is rich and that semantics does not seem to play a direct role in the selection of the construction types and their arguments in the lower clause. While putting together this list, I have relied on Erelt et al. (1993: 237-267) and on the corpus data I was able to find.

Table 10. Types of subject control in Estonian.

\begin{tabular}{l|l|l}
$\begin{array}{l}\text { Form of the } \\
\text { complement } \\
\text { verb }\end{array}$ & $\begin{array}{l}\text { Examples of the matrix } \\
\text { clause event/predicate }\end{array}$ & $\begin{array}{l}\text { Examples of the } \\
\text { complement clause } \\
\text { event/predicate }\end{array}$ \\
\hline (c) da-infinitive & $\begin{array}{l}\text { experience, intentional acti- } \\
\text { vity (soovima 'to wish'), } \\
\text { necessive construction } \\
\text { (vaja olema 'to be neces- } \\
\text { sary for somebody'), cap- } \\
\text { ability (suutma 'to be able } \\
\text { to'), modals (tulema 'to } \\
\text { have to', ähvardama 'to } \\
\text { threaten'), other (lubama } \\
\text { 'to promise', pü̈rdma'to }\end{array}$ & $\begin{array}{l}\text { tama 'to dress') and non- } \\
\text { times presented as agentive } \\
\text { (meelde jääma 'to stay in } \\
\text { mind'), static situations } \\
\text { (olema'to be') }\end{array}$ \\
\hline try')
\end{tabular}




\begin{tabular}{|c|c|c|}
\hline $\begin{array}{l}\text { Form of the } \\
\text { complement } \\
\text { verb }\end{array}$ & $\begin{array}{l}\text { Examples of the matrix } \\
\text { clause event/predicate }\end{array}$ & $\begin{array}{l}\text { Examples of the } \\
\text { complement clause } \\
\text { event/predicate }\end{array}$ \\
\hline (e) converb & $\begin{array}{l}\text { volitional, mental activities } \\
\text { (vaatama 'to look, to } \\
\text { watch', kogema 'to expe- } \\
\text { rience'), movement (jooks- } \\
\text { ma 'to run'), static situa- } \\
\text { tions (olema 'to be') co- } \\
\text { ming into existence (tekki- } \\
\text { ma 'to occur'), other (häiri- } \\
\text { ma 'to disturb'). }\end{array}$ & $\begin{array}{l}\text { volitional activities (ladu- } \\
\text { ma 'to lay'), movement } \\
\text { (käima 'to go'), non-inten- } \\
\text { tional events (komistama } \\
\text { 'to stumble'), static situat- } \\
\text { ions (olema 'to be'), expe- } \\
\text { rience (meeldima 'to be } \\
\text { likeable'), verbs in passive } \\
\text { (sunnitud olema 'to be for- } \\
\text { ced to'). }\end{array}$ \\
\hline $\begin{array}{l}\text { (f) relative } \\
\text { participle } \\
\text { (relativization) }\end{array}$ & no restrictions & $\begin{array}{l}\text { agentive activities (purus- } \\
\text { tama 'to break'), mental } \\
\text { activities (meenuma 'to } \\
\text { come to mind'), non-agen- } \\
\text { tive situations (kasvama 'to } \\
\text { grow'), static situations } \\
\text { (toetuma 'to lean') }\end{array}$ \\
\hline
\end{tabular}

Table 11. Types of object control in Estonian.

\begin{tabular}{l|l|l}
$\begin{array}{l}\text { Form of the } \\
\text { complement } \\
\text { verb }\end{array}$ & $\begin{array}{l}\text { Examples of the matrix } \\
\text { clause event/predicate }\end{array}$ & $\begin{array}{l}\text { Examples of the } \\
\text { complement clause } \\
\text { event/predicate }\end{array}$ \\
\hline $\begin{array}{l}\text { (g) da-infinitive } \\
\text { 'to order'), other (võimal- } \\
\text { dama 'to enable') }\end{array}$ & $\begin{array}{l}\text { volitional activities (rääki- } \\
\text { ma 'to tell'), non-volitional } \\
\text { activities (kartma 'to be af- } \\
\text { raid'), movement (lahkuma } \\
\text { 'to leave'), static situations } \\
\text { (olema 'to be') }\end{array}$ \\
\hline $\begin{array}{l}\text { (h)supine (-ma, } \\
\text {-mast) }\end{array}$ & $\begin{array}{l}\text { causation (keelitama 'to } \\
\text { persuade' kutsuma 'to } \\
\text { invite') }\end{array}$ & $\begin{array}{l}\text { volitional activities (otsima } \\
\text { 'to search for'), non-voli- } \\
\text { tional activities (suubuma } \\
\text { 'to flow into'), static } \\
\text { situations (olema 'to be') }\end{array}$ \\
\hline $\begin{array}{l}\text { (f) relative } \\
\text { participle } \\
\text { (relativization) }\end{array}$ & see Table 10 & see Table 10 \\
\hline
\end{tabular}


(c) Pivot of a subject control construction (taking $d a$-infinitive)

Active unmarked basic clauses occur productively in this interclausal construction (I assigned both 2 points). In rare cases, passives and experiential constructions also do, with the d-S and St passing the test (1 point on the subjecthood score). For example:

(62) Aga mina püüd-si-n oma imaago-t lakeeri-da.

but I.N try-PST-1SG own.G image-P embellish-INF

'But I was trying to embellish my image.' (A)

(63) Homme on mei-1 kõigi-l vaja

tomorrow be. 3 we-AD all-AD necessary

kooli-s oll-a riieta-tud punase-sse.

school-IN be-INF dress-IMPS.PST.PTC red-ILL

'Tomorrow we all need to be dressed in red at school.' (d-S)

(64) Midagi (St) $\varnothing \quad$ hästi meelde jää-da ei taha. anything (I-AD) well in.mind stay-INF NEG want

'Nothing tends to stick in (my) memory very well.' Lit. 'Nothing well in memory stay does not want.' (Google) (St)

In the last example, the stimulus is conceptualized as affecting the covert experiencer argument. The usage shift of the verb tahtma 'to want' to the unintentional, more grammatical use (cf. Heine and Miyashita 2008) allows it to take complement structures denoting unintentional processes.

The test construction (c) excludes most of the argument types of marked basic clauses from the pivot position: I found no examples of possessive clauses, resultatives and existential constructions combined with the (c) test ( 0 points for their arguments). The distribution of the test (c) property is shown in Table 12.

Table 12. Test (c): The occurrence of different argument types as pivots of subject control constructions with the $d a$-infinitive.

\begin{tabular}{l|c|c|c|c|c|c|c|c|c|c} 
Criterion & A & S & d-S & Exp & St & Pr & Pe & So & Gr & e-NP \\
\hline Subject control (da-infinitive) & 2 & 2 & 1 & 0 & 1 & 0 & 0 & 0 & 0 & 0
\end{tabular}

An argument's privileged treatment in the subject control construction with the $d a$-infinitive is dependent on the argument's coding: with some exceptions, nominative(-permitting) arguments pass the test. 
(d) Pivot of a subject control construction (taking supine)

Unmarked lower clauses occur productively in this subject control construction and are therefore assigned 2 points in the subjecthood measure.

(65)

(Vedelik kõrveta-s nagu kee-v tina,)

liquid.N burn-PST.3SG like boil-PTC tin.N

aga $\varnothing \quad$ kurgu-st alla mahtu-s mine-ma küll

but liquid.N throat-EL down fit-PST.3SG go-INF indeed

'(The liquid burnt (me) like boiling tin) but could indeed fit (going) down the throat.' (e.g. in the context of drinking strong alcohol) (S with the undergoer meaning, see also 0 for $\mathrm{A}$ )

I did not find any examples of passive, possessive, resultative and existential constructions occurring with the (d) test construction $(0$ points in the subjecthood score for all their arguments). Usually experiential construction arguments are not subject-like with respect to the (d) test either. St can occur in rare occasions as the (d) test pivot if there is a shift in its usage and there comes a nuance of deliberate action to its meaning (1 point). In these cases, the translative form of the supine is used.

See on disaini-tud $\quad$ meeldi-ma-ks naise-le.
this.N be.3 design-PAST.PASS.PTC be.likeable-INF-TR woman-ALL
'This has been designed to attract women.' Lit. 'This has been designed
to be likeable for the woman.' (St)

The following table summarizes the (d) test results.

Table 13. Test (d): The occurrence of different argument types as pivots of subject control constructions with the supine.

\begin{tabular}{l|c|c|c|c|c|c|c|c|c|c} 
Criterion & A & S & d-S & Exp & St & Pr & Pe & So & Gr & e-NP \\
\hline Subject control (supine) & 2 & 2 & 0 & 0 & 1 & 0 & 0 & 0 & 0 & 0
\end{tabular}

An argument's privileged treatment in the subject control construction with the supine is mainly reserved for active unmarked clause arguments. Exceptionally also St passes the test but the experiential clause largely resembles the unmarked clause. I suggest the test depends on coding (and clause type). 


\section{(e) Pivot of a subject control construction (taking converbs)}

The converb construction expresses an event taking place at the same time as the matrix clause event and sometimes it expresses an event taking place immediately before or after the matrix clause event (Erelt et al. 1993: 263). In the data there are examples with active and passive unmarked basic clauses, as well as experiential constructions participating in test (e) constructions. Active transitive and intransitive clauses and passive clauses occur productively in this construction and are assigned 2 points on the subjecthood score. For example:

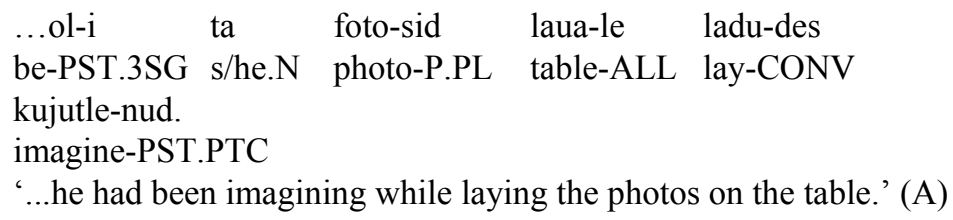

(68) (Ta mäleta-vat,) et ta lõpuks ohtliku-st koha-st s/he.N remember-QUO that s/he.N finally dangerous-EL place-EL eemale jooksu-nud, komista-des karjamaa mätas-te otsa. away run-PST.PTC stumble-CONV pasture.G turf-PL.G on '(He is said to remember) that he finally had run away from the dangerous place while stumbling on the pasture's turf.' (S with undergoer semantics)

(69) Oll-es

$$
\text { vahepeal }
$$

sega-tud

Saksa

being-CONV in.the.meanwhile involve-IMPS.PST.PTC German revolutsiooni, pid-i ta rända-ma läbi Euroopa. revolution.ILL have.to-PST.3SG he roam-INF through Europe.G 'As he was involved in the German revolution in the meanwhile, he had to roam through Europe.' (d-S)

In rare cases, e-NP also occurs in this position.

(70)

$\begin{array}{lllll}\text { Haiguse } & \text { esinemissagedus } & \text { ol-i } & \text { väike, } \\ \text { disease.G } & \text { occurrence.frequency.N } & \text { be-PST.3SG } & \text { small.N } \\ \text { leidu-des } & 3 & \text { protsendi-1 } & \text { uuritu-te-st. } & \\ \text { occur-CONV } & 3 & \text { percent-AD } & \text { subject-PL-EL } & \end{array}$

'The occurrence frequency of the disease was small, appearing only in 3 percent of the subjects.' (e-NP)

Marginally it is also possible to construct examples with the Pe as a controllee but such examples are questionable for the intuition of a native speaker. 
(71) ?Oll-es ol-nud mu-l kaks aasta-t, be-CONV be-PST.PTC I-AD two.N year-P hakka-s auto lagune-ma. start-PST.3SG car.N fall.apart-INF

'After I had had the car for two years, it started to fall apart.' (Pe)

With the experiential construction, a semantic shift towards the agentive unmarked clause takes place (cf. Lindström 2012 on Estonian agentive experientials):

(72) Inimes-te-le meeldi-des saavuta-me rahulolu. person-PL-ALL be.likeable-CONV achieve-1PL satisfaction.G 'We achieve satisfaction when we are pleasing (likeable) to people' (Google) (St)

In 73 it seems to be the (covert) Exp that is the pivot:

(73) Elmari-1 on kaustik töö juures, Elmar-AD be-3 notebook.N work.G at $\varnothing$ mõtte tull-es märgi-b kohe sinna üles. (he-AD) idea.G come-CONV mark-3SG right.away there up 'Elmar has the notebook at work, when (he) gets an idea he marks it down there immediately.' Lit. '... an idea coming (to him) he marks it down immediately.' (Exp?)

As the Exp is not overt, the lower clause in (73) could also be interpreted as an existential construction (with mõtte as e-NP) that does not have a coreferent argument in the matrix clause. This is the only test (e) example that I was able to find with a potential Exp pivot. As it is also ambiguous, I rate the Exp as not having this subjecthood property (0 points). The St argument sometimes occurs in the pivot position, but not as productively as the unmarked basic clause arguments (it receives 1 point on the subjecthood score). I did not find any examples of the possessive, existential and resultative constructions ( 0 points for all their arguments). Table 14 summarizes the (e) test results.

Table 14. Test (e): The occurrence of different argument types as pivots of subject control constructions with converbs.

\begin{tabular}{l|l|l|l|l|l|l|l|l|l|l} 
Criterion & A & S & d-S & Exp & St & Pr & Pe & So & Gr & e-NP \\
\hline Subject control (converb) & 2 & 2 & 2 & 0 & 1 & 0 & 0 & 0 & 0 & 1
\end{tabular}


In conclusion, only unmarked clause arguments pass test (e) productively. Out of marked basic clause arguments, only e-NP and St can receive privileged syntactic treatment but not as frequently as the unmarked subjects. An argument's privileged treatment in the subject control construction with the converb is dependent on the argument's case.

\section{(f) Relativization (participial subject and object control con- structions)}

In participial control constructions, present participles usually express an event continuing at the time of the matrix clause event, while past participles express an event that took place before the matrix clause event (Erelt et al. 1993: 266). There are active participles (present and past participles that have the $-v$ and $-n u d$ markers respectively) and passive participles (present and past participles that have the -tav and -tud markers). Participial pivot can be controlled by various arguments and adjuncts without this having any noticeable effect on them, therefore it is useful to discuss participial subject control and object control together in this section.

The subjects of both active and passive unmarked basic clauses occur productively in the pivot role of relative participial constructions. Test (f) constructions with participles formed from marked clauses are less common. In the data there are subject and object control examples of participial constructions formed of all four marked basic clause construction types. The marked clause arguments that pass the test are the nominative-permitting ones (e-NP, Pe, St and Gr). To illustrate the phenomenon, in the following I will focus on subject control. I will start with unmarked basic clause subjects.

$\begin{array}{lllll}\text { Rätiku-t } & \text { müü-v } & \text { mutt (A) } & \text { taha-ks } & \text { tingi-da. } \\ \text { shawl-P } & \text { sell-PTC } & \text { old.woman.N } & \text { want-COND } & \text { bargain-INF }\end{array}$

'The old woman who is selling the shawl would like to bargain.' (subject control, A)

The participial construction corresponds to the following finite clause:

(75) Mutt (A) müü-b rätiku-t.

old.woman.N sell-3SG shawl-P

'The old woman is selling a shawl.'

Also active intransitive and passive subjects can occur as pivots of this type of subject control: 
(76) Ainult mõni kilomeeter põhja pool on only a.few.N kilometre.N North.G side be.3 elanik-e-st tühja-ks jookse-v Saksa provints (S). inhabitant-PL-EL empty-TR run-PTC German province.N 'Only a few kilometres northwards is a German province that is losing its inhabitants.' (subject control, S with undergoer semantics)

(77) Kõige tihedamini asusta-tud osa (d-S) põle-s most densely populate-PST.PASS.PTC part.N burn-PST.3SG maa-ni maha. earth-TERM down

'The most densely populated part burned down entirely.' (subject control, d-S)

The finite version of the participial clause in 77 would be:

(78) Osa (d-S) on kõige tihedamini asusta-tud. part.N be.3 most densely populate-PST.PASS.PTC 'The part is most densely populated.'

I will proceed with the examples of marked basic clause arguments in subject control constructions. I found examples of existential, possessive and experiential constructions occurring with relativization. For example:

(79) Esimese ehmatuse-ga meenu-v puuvili on eestlase-le first.G shock-COM occur-PTC fruit.N be.3 Estonian-ALL õun (St).

apple.N

'For an Estonian, the fruit that comes to mind first is apple.' (in a situation where one is asked to name fruits during a psychological experiment) (subject control, St)

(80) Mu-1 ole-v võim $(\mathrm{Pe})$ on $4 \times 50 \mathrm{~W}$.

I-AD be-PTC amplifier.N be. $3 \quad 4 \times 50 \mathrm{~W}$

'The amplifier I have is 4 x 50W.' (Google) (subject control, Pe)

Example 81 shows the finite version of the participle in 80 :

(81) $\mathrm{Mu}-1$ on võim $(\mathrm{Pe})$.

I-AD be.3 amplifier.N

'I have the amplifier.' 
(82) Millegipärast köit-si-d politseiniku tähelepanu for.some.reason attract-PST-3PL policeman.G attention.P riiuli-te-1 leidu-va-d ehteasja-d (e-NP). shelf-PL-AD be-PTC-PL.N jewelry.item-PL.N 'For some reason the jewelry items that were on the shelves attracted the policeman's attention.' (subject control, e-NP)

In the case of source-marking resultative constructions, I only found examples of object control, probably because this is the most specific and restrictively used construction studied.

(83) ... seitse patsienti, kelle-st üks kanna-b seven.N patient.P who-EL one.N carry-3SG doonori munarakku-de-st kasva-va-t loode-t. donor.G egg.cell-PL-EL grow-PTC-P fetus-P

'... seven patients of which one carries a fetus that is growing from the donor's egg cells.' (object control, Gr)

Due to their productive occurrence in test (f) constructions, the unmarked basic clause arguments and the St are given 2 points. As I was able to find very few examples with e-NPs, Pe-s and Gr-s, they have been given 1 point. This is also justified because Gr and subgroups of e-NP and Pe cannot participate in subject control constructions but they all can occur in object control constructions. The arguments that cannot receive privileged syntactic treatment have been given 0 points. The following table gives an overview of the test (f) results.

Table 15. Test (f): The occurrence of different argument types as pivots of relative constructions (participial subject and object control constructions).

\begin{tabular}{l|c|c|c|c|c|c|c|c|c|c} 
Criterion & A & S & d-S & Exp & St & Pr & Pe & So & Gr & e-NP \\
\hline $\begin{array}{l}\text { Relativization (participial } \\
\text { subject/object control }\end{array}$ & 2 & 2 & 2 & 0 & 2 & 0 & 1 & 0 & 1 & 1
\end{tabular}

The relativization test depends on the argument's case: only nominative(-permitting) arguments can pass it, while the oblique ones cannot.

(g) Pivot of an object control construction (taking $\boldsymbol{d a}$-infinitive)

Although this construction is called object control, in Estonian these are both partitive objects as well as oblique (adessive) arguments 
that control the pivot of the lower $d a$-infinitive clause. Often the choice between the partitive and the adessive is free and does not bring about any difference in meaning. For example:

(84) Grpowski käski-is mei-d/ mei-l sinna jää-da. Grpowski.N order-PST.3SG we-P/ we-AD there stay-INF 'Grpowski ordered us to stay there.' (S)

The corresponding finite counterpart of the infinitival construction in 84 is 85 (irrespective of the case of $m e$ 'we').

(85) Me jää-me sinna.

we stay-1PL there

'We will stay there.'

In the following example the pivot is a transitive clause subject:

(86) Arst käski-s ta-l ost-a peavalurohtu. doctor.N order.PST.3SG s/he-AD buy-INF headache.medicine.P.SG 'The doctor ordered him to buy painkillers (headache medicine).' (A)

Although there is an argument in the direct object case (peavalurohtu) in 86, it cannot be the controller as it is the object of the lower clause. In the data there are also examples with experientials and existentials but not of passives, possessives and resultatives. It is however possible to construct grammatical examples with the latter.

(87) Ära lase se-da meeldi-da enda-le. IMPNEG let this-P be.likeable-INF self-ALL 'Don't let yourself like it.' (St)

(88) Ei tohi las-ta südalinna tekki-da sobimatu-id NEG may let-INF city.centre.ILL appear-INF unsuitable-PL.P maj-u.

building-PL.P

'We should not let unsuitable buildings appear in the city centre.' (e-NP)

(89) Ravi ei lase selle-st arene-da tuberkuloosi. cure.N NEG let this-EL develop-INF tuberculosis.P

'The cure will not let it develop into tuberculosis.' (HM) (Gr) 
Table 16. Test (g): The occurrence of different argument types as pivots of object control constructions with the $d a$-infinitive.

\begin{tabular}{l|c|c|c|c|c|c|c|c|c|c} 
Criterion & A & S & d-S & Exp & St & Pr & Pe & So & Gr & e-NP \\
\hline $\begin{array}{l}\text { Object control (da- } \\
\text { infinitive) }\end{array}$ & 2 & 2 & 0 & 0 & 1 & 0 & 0 & 0 & 1 & 1
\end{tabular}

Only active unmarked basic clause subjects appear productively in test (g) constructions ( 2 points). The St, e-NP and Gr have a restricted distribution in this construction (1 point). Passive subjects and marked clause oblique arguments, as well as the Pe do not pass this test (0 points). An argument's privileged treatment in the object control construction with the $d a$-infinitive is dependent on coding (and construction type).

\section{(h) Pivot of an object control construction (taking supine)}

Usually only active unmarked clause arguments occur as pivots of this object control construction. They are therefore assigned 2 points in the subjecthood score.

(90) Ma pole sin-d kunagi näi-nud ajalehte ost-ma-s. I.N be.NEG you-P never see-PST.PTC newspaper.P buy-INF-IN 'I have never seen you buying a newspaper.' (A)

(91) Hendrik saada-b Jussikese USA-sse õppi-ma. Hendrik.N send-3SG Jussike.G United.States-ILL study-INF 'Hendrik will send Jussike to study in the United States.' (S)

Restrictedly, also experiential, existential and resultative clauses can appear in this context. The St, e-NP and Gr are assigned 1 point.

(92) Kujutle-n se-da enda-le meeldi-ma-s. imagine-1SG this-P self-ALL be.likeable-INF-IN 'I imagine myself liking it.' (St) ${ }^{24}$

(93) Laua taga näe-me istu-ma-s kolmeteistkümme-t inimes-t. table behind see-2PL sit-INF-IN 13-P person-P 'We see 13 people sitting at the table.' (e-NP)

24 I thank the anonymous reviewer for this example. I was unable to find any examples from the corpus or the internet on such uses. 


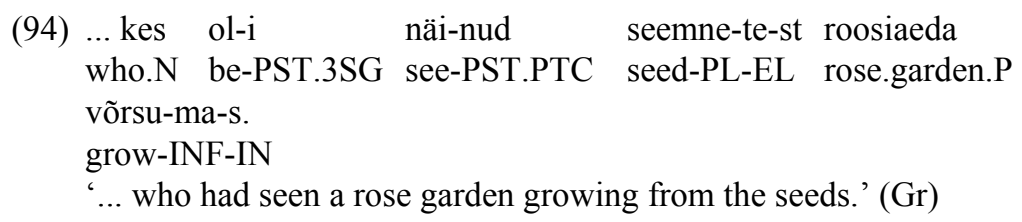

I could not find any examples with passive and possessive clauses in this construction (all the arguments get 0 points). Table 17 summarizes the test results.

Table 17. Test (h): The occurrence of different argument types as pivots of object control constructions with the supine.

\begin{tabular}{l|c|c|c|c|c|c|c|c|c|c} 
Criterion & A & S & d-S & Exp & St & Pr & Pe & So & Gr & e-NP \\
\hline Object control (supine) & 2 & 2 & 0 & 0 & 1 & 0 & 0 & 0 & 1 & 1
\end{tabular}

An argument's privileged treatment in the subject control construction with the supine is dependent on case (and construction type): most of the nominative(-permitting) arguments can participate in the test construction but only the unmarked active clause ones do it productively.

\subsection{Other subjecthood properties}

(i) Reflexive pronoun binding

Reflexivization is in general considered to be more suitable for identifying topics or other discourse variables, and not subjects (cf. Bickel 2010: 432; Hakulinen et al. 2004). However, the Estonian reflexive pronouns prove to be a valid subject test as only subjects but not objects or adjuncts can act as their antecedents. Though, the antecedents indeed are in most cases topical. The Estonian reflexives include enese, enda, iseenese, iseenda 'my-/your-/him-/herself, our/your-/themselves' (the words are all synonymous, the ones with iseare more emphasized). They occur in sentences as an independent NP or in an adposition phrase. Most of these pronouns can also be used possessively when they are in the modifier position (see the next subsection).

When deciding upon the applicability of the (i) test on the data, I only looked at intraclausal binding. The antecedents of reflexive pronouns are usually the A and S arguments (they only received 1 point in the subjecthood ranking due to the ban on inanimates). There are fewer examples in my data of Pr, Exp, St and So arguments in this position (1 point). Hence reflexive binding is the first behaviour test 
that two arguments of the same argument structure construction can clearly pass: the Exp and St arguments of the experiential construction. This shows again that experiential constructions are one of the most varied construction types where both arguments can have prominent semantics and treatment (cf. Næss 2007). I did not find any examples of d-S, e-NP, Pe and Gr and assigned them therefore 0 points.

(95) Selle korteri ost-si-n enda-le.

this.G flat.G buy-PST-1SG self-ALL

'I bought this flat for myself.' (A)

(96) Ta (S) ei pääse enese sisse.

$\mathrm{s} / \mathrm{he} \quad \mathrm{NEG}$ get self.G in

'He cannot get in himself.' (S with undergoer meaning)

(97) Ta-lle (Exp) tul-i enda kohta midagi meelde. s/he come-PST.3SG self.G about something.P in.mind 'Something occurred to him about himself.' (Exp)

(98) Üle hulga aja ta (St) meeld-is jälle enese-le. over a.lot.G time.G s/he.N be.likeable-PST.3SG again self-ALL 'Over a long time he liked himself again.' (St)

(99) Nei-1 liiderdaja-i-l (Pr) pol-nud enda-st these-AD hedonist-PL-AD be.NEG-PST.PTC self-EL se-da kuulsa-t maali. this-P famous-P painting.P 'These hedonists did not have this famous painting of themselves.' (Pr)

(100) Jüri-st (So) kujune-s enda kohta üllatavalt hea Jüri-EL develop-PST.3SG self.G about surprisingly good.N teadlane. scientist.N

'For himself (by the standard of what was expected of him) Jüri became a surprisingly good scientist.' (So)

It is suprising that $\mathrm{d}-\mathrm{S}$ cannot participate in this construction as all the other predominately topical arguments can. One might think that this is caused by d-S' undergoer semantics, however, also undergoer $\mathrm{S}$ can antecede reflexives, see (96). 
Table 18. Test (i): The occurrence of different argument types as antecedents of reflexive pronouns.

\begin{tabular}{l|c|c|c|c|c|c|c|c|c|c} 
Criterion & A & S & d-S & Exp & St & Pr & Pe & So & Gr & e-NP \\
\hline $\begin{array}{l}\text { Antecedece of a reflexive } \\
\text { pronoun }\end{array}$ & 1 & 1 & 0 & 1 & 1 & 1 & 0 & 1 & 0 & 0
\end{tabular}

Whether an argument passes the reflexive test depends on animacy and topicality.

\section{(j) Possessive pronoun binding}

Possessive pronouns are for example oma, enese, enda, omaenese, iseenda 'his, her, its, their, own' in Estonian and they serve as NP modifiers. In the case of coreference, the use of a possessive pronoun is obligatory with semantic subjects: possessive pronoun binding is a characteristic feature of semantic subjects in Estonian (Erelt et al. 1993: 12) ${ }^{25}$ Antecedents of possessive pronouns are usually topical. For example:

(101) Ta on pan-nud oma ütluse kirja. s/he be. 3 put-PST.PTC own.G utterance.G in.written 'He has written down his utterance.' (A)

For comparison, the typical way of referring possessively to direct objects is using the pronouns $t a$ 's/he' and see 'it, this'. On rare occasions, direct objects can antecede possessive pronouns. For example in the situation where the object referent is active and agentive, the reference of oma is ambiguous:

$$
\begin{aligned}
& \text { Ma saat-si-n Peetri oma sõbra juurde. } \\
& \text { I.N send-PST-1SG Peeter.G own.G friend.G to } \\
& \text { 'I sent Peter to my/his friend.' (HM) (A or O) }
\end{aligned}
$$

Also in some frozen constructions (e.g. oma kohale 'to its place') oma seems to have an object antecedent.

(103) Pane nõu-d oma koha-le tagasi. put.IMP dish-PL.N own.G place-ALL back 'Put the dishes back in their place.' (HM) (O)

25 What is meant by the semantic subject in (Erelt et al. 1993) is the most agentive argument in the clause. It can be either the prototypical subject or for example an oblique subject-like argument (cf. ibid.: 12). 
As the cases where the object is the clear antecedent of the possessive pronoun are very exceptional, it is possible to use the possessive pronoun binding as a subject criterion. In the data, possessive pronoun binding occurred with all construction types, except for the existential construction. The arguments that appear as antecedents are A, S, d-S, So, Pr, Exp and St. Hence possessive pronoun binding is the second test in this study where clearly both Exp and St of the experiential construction show subject-like behaviour.

(104) Mina sündi-si-n oma talu sauna-s.

I.N be.born-PST-3SG own.G farm.G sauna-IN

'I was born in the sauna of my farm.' (S with undergoer semantics)

(105) Ta ol-i oma elu edu-st mõnevõrra s/he.N be-PST.3SG own.G life.G success-EL somewhat segadusse ae-tud. confusion.ILL drive- PASS.PST.PTC

'He was somewhat confused by the success of his own life.' (d-S)

(106) Mu-1 ei ole oma korterivõtme-i-d kaasas.

I-AD NEG be own.G flat.key-PL-P along

'I do not have my flat keys along.' (Pr)

(107) Kas tei-1 meenu-b oma töö-st naljaka-i-d Q you.PL-AD come.to.mind-3SG own.G work-EL funny-PL-P juhtume-id? incident-PL.P

'Do any funny incidents from your work come to your mind?' (Exp)

(108) Ja ometi meeldi-si-d oma erinevuse-st and nevertheless be.likeable-PST-3PLown.G difference-EL hoolimata mu-lle mõlema-d. despite I-ALL both-PL

'And nevertheless, despite their differences I liked them both.' (St)

(109) Karbi-st saa-b oma elu lõpu-1 isane või shellfish-EL become-3SG own.G life.G end-AD male.N or emane isend. female.N specimen.N 'At the end of its life the shellfish (i.e. every shellfish) becomes a male or a female specimen.' (So) 
Although I was unable to find examples of e-NPs that bind possessives, it is still possible to construct such sentences. The following example is translated from Finnish and is grammatical (though it feels slightly cumbersome):

(110) Inimes-i istu-b oma aeda-de-s. person-PL.P sit-3SG own.G garden-PL-IN

'There are people sitting in their gardens.' (from Vilkuna 1989: 158) (e-NP)

A, S, d-S, So, Exp, St and Pr antecede possessives frequently and are assigned 2 points on the subjecthood score. e-NP, Pe and Gr are given 0 points. See Table 19 for a summary of the possessive construction.

Table 19. Test (j): The occurrence of different argument types as antecedents of possessive pronouns

\begin{tabular}{l|c|c|c|c|c|c|c|c|c|c} 
Criterion & A & S & d-S & Exp & St & Pr & Pe & So & Gr & e-NP \\
\hline $\begin{array}{l}\text { Antecedence of a possessive } \\
\text { pronoun }\end{array}$ & 2 & 2 & 2 & 2 & 2 & 2 & 0 & 2 & 0 & 0
\end{tabular}

Whether an argument passes the reflexive test or not depends on topicality.

\section{(k) Impersonal}

Impersonal can be formed of both transitive and intransitive clauses (see section 4). Only the verbs whose personal forms take a human actor referent marked by the nominative can be impersonalized (Torn-Leesik 2009: 77). Examples of impersonalized transitive and intransitive constructions are (111) and (112).

(111) ... kuhu ehita-takse järgmine varjualune. where build- IMPS next.N shelter.N

'... where the next shelter will be built.' (A)

(112) vare-m või hilje-m kuku-ti selle-ga sisse. early-COMP or late-COMP fall-PST.IMPS this-COM in 'Sooner or later one was caught out (Lit. fell in) with it.' (S with undergoer semantics)

What is also not so rare cross-linguistically is that Estonian passive constructions can be impersonalized. In this case, the passive subject 
becomes suppressed and the auxiliary olema 'to be' receives the impersonal marking (Torn-Leesik: 2009 86). Compare:

(113) Me ole-me märga-tud.

we.N be-1PL notice-PASS.PST.PTC

'We have been noticed.' (d-S, personal passive)

(114) Mei-d oll-akse märga-tud.

we-P be-IMPS notice-PASS.PST.PTC

'We have been noticed. / One has noticed us.' (demoted d-S, impersonalized passive)

Erelt (2011: 27-28) finds that of different Estonian construction types the e-NP and the St of the verbs meeldima 'to be likeable' and meenuma 'to come to mind' can be impersonalized whereas the oblique arguments and the Pe of possessive construction as well as the Gr of the source-marking resultative construction cannot be. In my data, there were some examples of marked clauses with impersonalized experiencer clauses, but they co-occurred with a shift towards unmarked agentive clauses.

(115) Vale jutt, meeldi-takse ühtmoodi. wrong.N story.N be.likeable-IMPS in.the.same.way 'This is wrong, (everyone) is likeable (to other people) in the same way.' (St)

In (115) the identity of neither the deleted St nor the elliptical Exp is quite clear from the context. Of existential constructions only those can be impersonalized that have a predicate that expresses an activity or process, not just mere existence (Erelt 2011: 27). For example:

(116) Kontserdi-le tule-b inimesi Helsingi-st ja Bakuu-st. concert-ALL come-3SG person.PL.P Helsinki-EL and Baku-EL 'People are coming to the concert from Helsinki and Baku.' (personal existential)

(117) Kontserdi-le tull-akse Helsingi-st ja Bakuu-st. concert-ALL come-IMPS Helsinki-EL and Baku-EL 'People are / They are coming to the concert from Helsinki and Baku.' (deleted e-NP, impersonalized existential)

The impersonal constructions are most common with the unmarked basic clause subjects and passive subjects (they are only given 1 point 
due to the ban on inanimates). In rarer cases the St and e-NP can also be deleted via impersonalization (1 point). Table 20 shows the results of the impersonal test.

Table 20. Deletion or demotion under impersonalization.

\begin{tabular}{l|c|c|c|c|c|c|c|c|c|c} 
Criterion & A & S & d-S & Exp & St & Pr & Pe & So & Gr & e-NP \\
\hline Impersonals & 1 & 1 & 1 & 0 & 1 & 0 & 0 & 0 & 0 & 1
\end{tabular}

Whether an argument passes this test or not depends on animacy and the argument's coding.

\subsection{The properties not chosen as subjecthood criteria}

The potential subjecthood tests that turned out not to be suitable for determining subjecthood were occurrence in conjunction reduction, reciprocal constructions and occurrence in the controller position and in imperatives.

Conjunction reduction. In Estonian, it is usually the subject that is deleted in coordinated clauses.

$\begin{array}{lllll}\text { Poisi-d } & \text { on uju-ma-s } & \text { või } \varnothing & \text { mängi-vad } \\ \text { boy-PL.N } & \text { be.3 } 3 \text { swim-INF-IN } & \text { or } & \text { boy-PL.N } & \text { play-3PL } \\ \text { jalgpalli. } & & & & \\ \text { football.P } & & & \end{array}$

'The boys are either swimming or playing football.'

However, it has been suggested that conjunction reduction is rather related to topichood (Bickel 2004). It can also occur with objects in Estonian (Hiietam 2003: 142):
Aeda kaunista-s põõsastik ja $\varnothing$ ümbritse-s garden.P decorate-PST.3SG shrub.N and it.P surround-PST.3SG hekk.
hedge. $\mathrm{N}$
'The shrub decorated the garden and the hedge surrounded (it).'

Lindström (2004: 42) has shown that even in the case of coordinated subjects, we interpret subject deletion under coordination as highly questionable if one of them is not the topic:

$\begin{array}{lllll}\text { *Hullunud } & \text { kana } & \text { tapp-is isa } & \text { ja } & \varnothing \\ \text { (mad.N } & \text { hen.N } & \text { kill-PST.3SG father.N } & \text { and } & \text { he/it.N }\end{array}$


keet-is ta supi-ks.

cook-PST.3SG he/it.G soup-TR

'The father killed a mad hen and cooked soup from it.' or 'A mad hen killed the father and cooked soup of him.'; Lindström 2004; glosses added)

Using a native-speaker's grammatical knowledge, one would expect the sentence-initial NP to be the controller of the second clause's pivot but our world knowledge tells us that it is impossible; therefore the sentence does not make sense. For these reasons I did not use conjunction reduction as a subjecthood criterion.

Binding reciprocals. Estonian reciprocal pronouns can have both subjects and objects as their antecedents (Erelt et al. 1993: 204), hence it is not a subject-specific property.

Controller of control constructions. It has been suggested that occurrence in the controller position is a subjecthood property in Estonian:

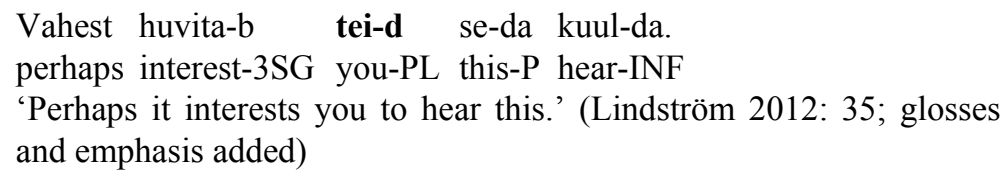

I find that unlike pivothood, this property does not distinguish subjects from objects - the objects can also occur in the controller position (see sections $6.3(\mathrm{~g})$ and $(\mathrm{h})$ ).

Imperatives. The omission of subjects in the imperative clauses is in some languages used as a subjecthood test. However, in Estonian, objects and other arguments can also be omitted. Similarly to Hiietam (2003: 144-145) I did not include the imperative test to the Estonian subjecthood criteria. Also, a great number of $\mathrm{A} / \mathrm{S}$ arguments that do not have agentive semantics fail the imperative test.

\section{Discussion}

Sections 5 and 6 looked at the Estonian subject's coding and behavioural properties. Two syntactic clause types were distinguished: the unmarked basic clause where the topic is a fully grammaticalized nominative subject and the marked basic clause where the topic is not a fully grammaticalized subject but an oblique or an adverbial. Within the unmarked basic clause type, three constructions were studied: 
1) the transitive construction (active, with the structure $N-V-$ $P / G / N-(X))$

2) the intransitive construction (active, $N-V-(X)$ );

$3)$ the passive construction $(N-V-(X))$.

Within the marked basic clause type, four constructions were studied:

4) the existential construction $((L o c)-V-N / P)$;

5) the possessive construction $(A D-V-N / P-(X))$;

6) the experiential construction $(A L L-V-N / P-(X))$ and

7) the source-marking resultative construction $(E L-V-N / P)$.

The purpose of the analysis was to identify how close the arguments of constructions (3)-(7) are to the tertium comparationis - the prototypical subjects (the transitive subject A in construction (1) and the intransitive subject $\mathrm{S}$ in construction (2)). More specifically, the following arguments were compared with the active unmarked clause subjects:

- the passive subject (d-S);

- the existential construction's nominative/partitive NP (e-NP);

- the possessive construction's possessor ( $\mathrm{Pr}$, in the adessive) and possessee ( $\mathrm{Pe}$, in the nominative or partitive);

- the experiential construction's experiencer (Exp, in the allative, sometimes adessive) and stimulus (St, in the nominative or partitive);

- the source-marking resultative construction's source (So, in the elative) and goal (Gr, in the nominative or partitive).

The arguments were compared using multivariate analysis: subjecthood was broken up into 16 language-specific parameters - subjecthood criteria (tests) (see Tables 21 and 22 below). They were evaluated in matrices using a three-point scoring system that proved successful in making this immense mass of complex data comprehensible and comparable in a simple way. The subjecthood criteria included 5 coding and 11 behavioural criteria. Of these criteria, 14 are rules and 2 (word order and zero-anaphora) are statistical properties. To make the statistical properties comparable, each argument type was assigned a score on the same three-point scoring system (see section 5). In this Radical Construction Grammar based study, the purpose of this analysis was to find out whether an argument can participate in a particular construction or not - a deeper discussion of the nature of those test constructions was of a lesser priority. ${ }^{26}$

26 Also Barðdal (2006: 82) uses the term 'raising' in quotation marks. 
The Estonian data show a clear division between active unmarked clause arguments (that, naturally, pass all of the tests) and the other subject-like arguments (they pass considerably fewer tests). As it was shown in sections 5 and 6 , these subjecthood criteria differ from each other considerably in the number of arguments that get subject-like treatment in them ( 7 out of 10 in possessive pronoun binding vs. only 3 out of 10 in zero-anaphora). Therefore the test constructions can be placed on a continuum according to their coverage among subjects and subject-like arguments. Croft (2001: 151) finds that the categories defined by coding constructions are less uniform across languages than those defined by behavioural constructions. The Estonian data of this study confirms it: the coding features tend to suit a wider range of arguments than the behavioural ones. This is related to the Hierarchy of Grammatical Relations Construction discussed for example in Barðdal (2006), Bickel (2010) and Croft (2001). I will claim below that the Hierarchy of Grammatical Relations Construction generally holds for the studied Estonian data.

It has been suggested that cross-linguistically the behaviour of arguments can for example depend on topicality, semantics, coding or grammatical relations (so that for example only topics, actors, nominative arguments or the $\mathrm{A} / \mathrm{S}$ arguments can pass a particular test respectively; Bickel 2004: 90-97; Kroeger 2004: 104; Van Valin and LaPolla 1997; Siewierska and Bakker 2012). In the following I will show that among Estonian subject-like arguments, all these factors are represented and suggest an additional factor - the syntactic construction type as a complex determinant (the marked - unmarked clause distinction) - which has a major influence.

In Table 21, each argument is evaluated in how close it is to the prototypical subject $(\mathrm{A} / \mathrm{S})$ with respect to each criterion. In each test the arguments could get either 2 points (the argument has the same value as the prototypical subject with respect to this property), 1 point (the argument shows a lower, in the case of behavioural properties often marginal, degree of subjecthood with respect to this property) or 0 points (the argument does not have this subjecthood property). 
Table 21. Distribution of coding and behaviour properties among the subject-like arguments.

\begin{tabular}{|c|c|c|c|c|c|c|c|c|c|c|c|c|}
\hline $\begin{array}{l}\text { Subject- } \\
\text { hood } \\
\text { test }\end{array}$ & Test type & $\begin{array}{l}\text { Which } \\
\text { arguments } \\
\text { pass } \\
\text { the test? }\end{array}$ & $\mathbf{A} / \mathbf{S}$ & d-S & St & $\mathbf{G r}$ & e-NP & $\mathrm{Pe}$ & Exp & Pr & So & Total \\
\hline 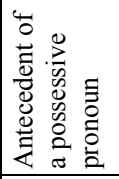 & 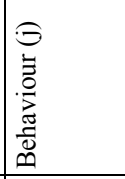 & 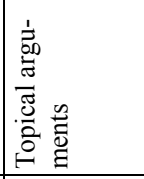 & 2 & 2 & 2 & 0 & 0 & 0 & 2 & 2 & 2 & 12 \\
\hline 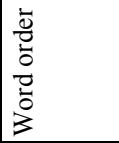 & . & 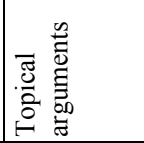 & 2 & 2 & 1 & 0 & 0 & 0 & 2 & 2 & 2 & 11 \\
\hline 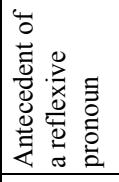 & 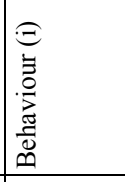 & 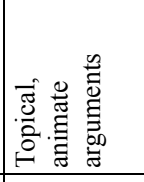 & 1 & 0 & 1 & 0 & 0 & 0 & 1 & 1 & 1 & 5 \\
\hline 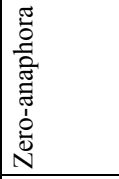 & 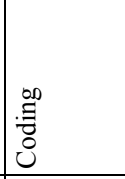 & 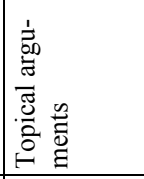 & 2 & 0 & 0 & 0 & 0 & 0 & 1 & 0 & 0 & 3 \\
\hline 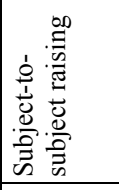 & 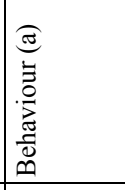 & 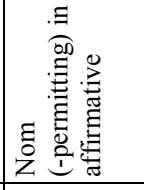 & 2 & 2 & 2 & 2 & 2 & 1 & 0 & 0 & 0 & 11 \\
\hline 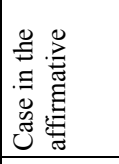 & 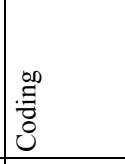 & 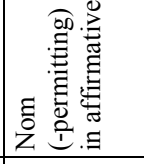 & 2 & 2 & 2 & 2 & 1 & 1 & 0 & 0 & 0 & 10 \\
\hline 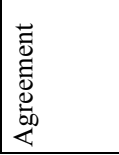 & : & 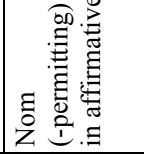 & 2 & 2 & 2 & 2 & 1 & 1 & 0 & 0 & 0 & 10 \\
\hline
\end{tabular}




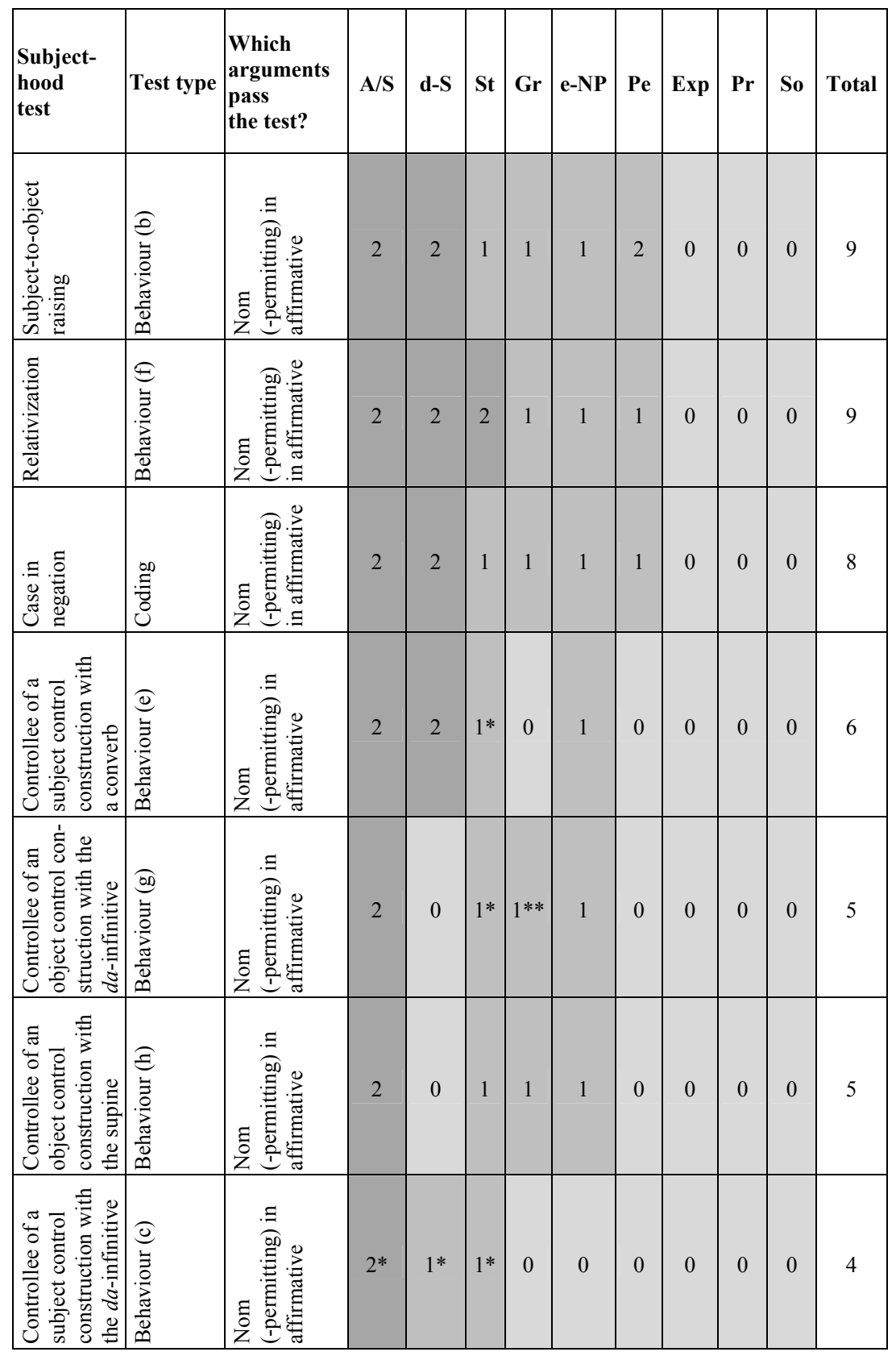




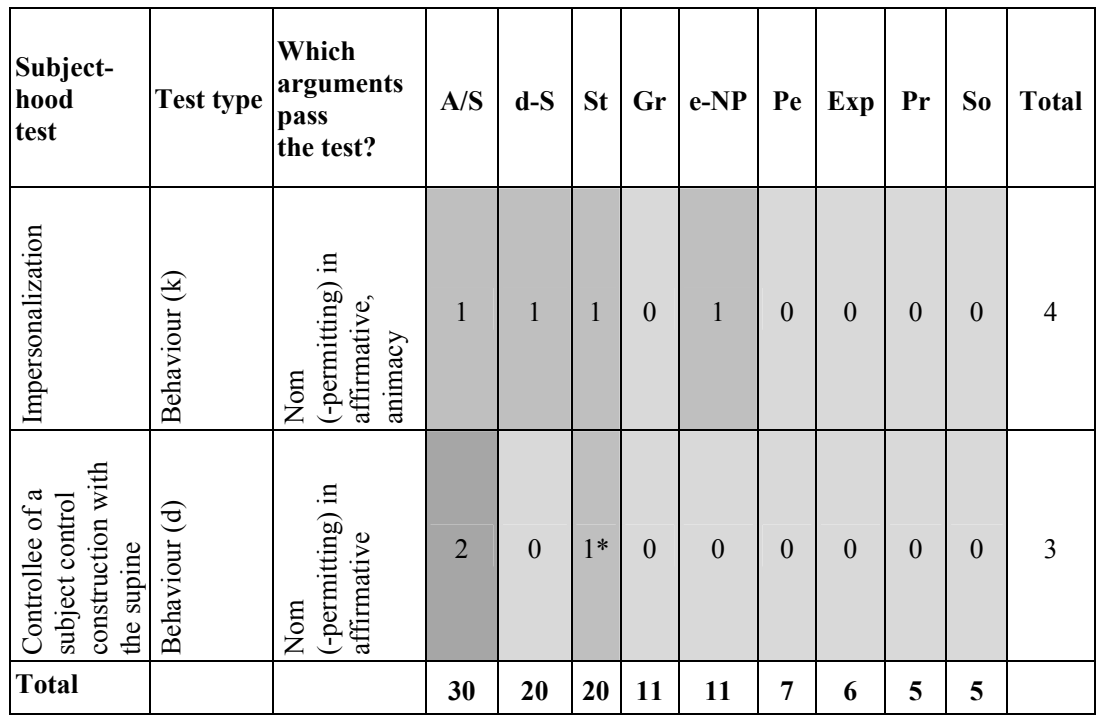

*In these test constructions inanimate referents only occur in the context of personalization.

**Examples only retrieved via introspection.

The semantic data from Table 1 at the end of section 4 has not been included here. The semantic and discourse properties of the arguments and their constructions require further research (see e.g. Metslang, to appear on the comparison of A, S, O and e-NP properties). For example, volitionality interpretation (personalization) seems to be an epiphenomenon of some inanimate marked clause arguments' occurrence in control test constructions.

There are two groups of different subjecthood tests where the arguments' success of passing them depends on the same factors. In the table, the tests are grouped according to the characteristics of the arguments that can pass them (the third column). For example, the tests of antecedence of pronouns and word order (prevailing preverbal position) group together because they can only be passed by topical arguments. These groups only mark tendencies and not absolute divisions (e.g. although antecedence of reflexive pronouns belongs to the group of tests that can in general be passed by topical arguments, d-S cannot pass it).

The arguments in Table 21 have been ordered according to their global subjecthood scores (the row Total). The scores are influenced by the fact that agreement and case were taken as the basis of evaluation in some behaviour tests (the results would be different if subject-like behaviour was determined on the basis of e.g. word order or semantics). The scores also depend on the fact that each of the 16 
tests has been given equal weight. As several tests are clearly linked to each other, then the overall ordering of the arguments in their closeness to the prototypical subject may not reflect the reality in a balanced way. This contradicts the Radical Construction Grammar requirement that the various argument criteria that are proposed should be independent (cf. Croft 2001: 272). In Table 22 the two test groups have been collapsed and their average numeric values have been calculated. In this way the result should be more accurate, with no group of properties being given an overly strong weight.

Table 22. Groups of subjecthood properties (rounded average values of each group's test results).

\begin{tabular}{|c|c|c|c|c|c|c|c|c|c|c|}
\hline $\begin{array}{c}\text { Which } \\
\text { arguments } \\
\text { pass the } \\
\text { test? }\end{array}$ & Arguments & A/S & d-S & St & Gr & e-NP & Pe & Exp & Pr & So \\
\hline $\begin{array}{c}\text { Typically } \\
\text { topical? }\end{array}$ & yes & yes & no (yes) & no & no & no & yes & yes & yes \\
\hline Topical arguments & 2 & 1 & 1 & 0 & 0 & 0 & 2 & 1 & 1 \\
\hline $\begin{array}{c}\text { Nom(-permitting) in } \\
\text { affirmative }\end{array}$ & 2 & 1 & 1 & 1 & 1 & 1 & 0 & 0 & 0 \\
\hline Total & $\mathbf{4}$ & $\mathbf{2}$ & $\mathbf{2}$ & $\mathbf{1}$ & $\mathbf{1}$ & $\mathbf{1}$ & $\mathbf{2}$ & $\mathbf{1}$ & $\mathbf{1}$ \\
\hline
\end{tabular}

In the table the arguments have been ordered according to clause type and topicality. The table shows that whether an argument passes a particular group of tests or not depends on simple features like topicality and case (rows 1 and 2). However, the overall degree of an argument's subjecthood rather depends on clause type which is then a composite feature (unmarked vs. marked clause arguments; indicated in the scores in the Total row). The impact of construction type cannot quite be ignored on the single tests' level either (e.g. (g) and (h)).

Group 1 entails reflexive and possessive pronoun binding, preference for preverbal position and zero-anaphora. These four criteria depend on topicality (it is also important that the successful arguments that pass these tests are subjects or subject-like arguments - objects fail these tests, as they also do in the case of the Group 2 tests). The topicality-based group (Group 1) gives subject-like treatment to an equally diverse set of arguments as Group 2 does.

The subjecthood criteria in Group 2 involve both coding and behaviour (as in Group 1) and they all depend on the argument's case (in 
the affirmative clause) (cf. Van Valin 2005 and Bickel 2003 on casesensitive pivots). Group 2 is the larger group in terms of the different tests it contains. The tests are passed by the nominative(-permitting) arguments. This holds for example in the case of constructions with raising verbs: they do not have semantic restrictions to the complement clause - their restriction for the argument choice is only formal. Also participial relativization constructions require nominative(-permitting) arguments as the pivot and prohibit oblique arguments. The latter may be related to the fact that the controller of the deleted pivot is an unmarked clause subject or object which cannot occur in an oblique case.

It is difficult to assign adequate weights to different factors without using statistical measures (Gries 2003). Therefore I suggest that Tables 21 and 22 should be looked at together in order to see the impact that different approaches to factor weights have on the subjecthood scores (depending on whether each test or each test group is given an equal weight). In the following I will discuss the overall subjecthood scores of the studied arguments.

In Table 22, the active unmarked clause subject $(\mathrm{A} / \mathrm{S})$ was used as tertium comparationis in the study and it has the highest subjecthood rating. It is noteworthy that the other argument types have significantly lower total scores. The arguments with the highest rating, the unmarked passive clause subject and the experiential clause's arguments, only have half of the A/S subjecthood score each. In the case of d-S, this may come from its grammaticalized undergoer semantics. Other marked clause arguments rank even lower. Hence, in Estonian the arguments of the marked clause constructions are not very subjectlike.

On the basis of Tables 21 and 22 it can be said that Estonian subject-like arguments form three groups. The typically topical oblique arguments (Exp, Pr and So) behave systematically differently than e-NP, Gr and $\mathrm{Pe}$ - the typically non-topical, nominative-permitting marked clause arguments. The overall subjecthood measures of these two marked clause argument groups are similar, however, in individual test groups their behaviour is different. I still consider the oblique topical marked clause arguments being less subject-like on the global level because they pass a considerably smaller number of tests and also two tests that they pass are the weaker, statistically based tests. Also d-S and St are treated very similarly with each other in both test groups. The very high position of the St in the subjecthood scores of all individual tests is possibly related to the fact that the experiential construction has some transitive clause properties: it has two participants, the situation is often conceptualized as dynamic (denoting a 
change of state, e.g. meelde tulema 'to recall, come to mind'), both the Exp and St can have some degrees of control over the situation. The latter fact is one of the reasons why there is a great variation both language-internally and cross-linguistically in the realization of experiential clauses (Næss 2007: 190). Næss finds that "a fundamental property of experience events is that they are difficult to classify in terms of the properties which define the transitive [clause] prototype." (ibid.). Why the St of this experiential construction $(A L L-V-N / P-$ $(X))$ is positioned so highly in the ordering of Estonian subject-like arguments should be studied further in future studies and it would also be interesting to juxtapose it with the data of other subtypes of experiential constructions. For comparison, the nature of prototypical existential and possessive constructions is not expressing dynamic events, and thus they also receive lower scores in Table 22. However, the source-marking resultative construction does express properly dynamic events (i.e. not only conceptualized as dynamic). The lower subjecthood rankings of its arguments may be caused by the construction's restricted meaning and use (see section 4).

To sum up, on the particular constructions level, the division of the studied arguments on the continuum between high and low subjecthood depends on topicality and case which, in turn, contribute to the arguments' total sums of overall (global) subjecthood. The total sums are characterized by a clause-type based division: the subjects of unmarked basic clauses have considerably higher subjecthood scores than the marked clause arguments; the two arguments that are positioned between the two groups are the passive subject and the experiential construction's stimulus. Clause type is a composite factor as it consists of topicality and argument structure case frames. Clause type also seems to play a role on the construction-specific level.

While Radical Construction Grammar does not see the subject as a universal category, it suggests that what might be cross-linguistically universal is the hierarchy of coding and behaviour constructions (cf. Croft 2001: 149). Bickel (2010) discusses the implicational Hierarchy of Grammatical Relations Constructions and suggests that it is likely that cross-linguistically arguments' treatment follows the scale below:

case $>$ agreement $>$ relativization / focus / operator floating $>$ conjunction reduction $>$ coreference constructions / coreference marking

The hierarchy was first applied for assessing the spread of ergativity and accusativity in languages. Later it was also applied to the analysis of phenomena that are not linked to ergativity (e.g. the 
grammaticalization of subjecthood properties on oblique subject-like arguments; Croft 2001: 155-159). In the scale, case is the highest ranked construction and the coreference features are the lowest ranked ones. The coreference constructions involve here for example control. Bickel explains the hierarchy as follows: "[E]rgatively-aligned grammatical relations in lower-ranking constructions in a language increase the odds for such grammatical relations in higher-ranking constructions in the same language." (ibid.) This means that according to the hierarchy, case is more likely to be diverse (e.g. objects being casemarked in the same way as intransitive subjects) than behavioural constructions (e.g. only subjects and not objects being able to occur as pivots of control constructions).

The Estonian subjects and subject-like arguments generally follow this scale well (see Table 21). According to how diverse sets of arguments these constructions take, the following scale could be constructed:

\section{case / agreement $>$ relativization $>$ control}

The Estonian data also supports the cross-linguistic generalization that "case marking is not particularly correlated with a higher degree of topicality" (Croft 2001: 160). In future research the applicability of the Hierarchy of Grammatical Relations Constructions could be studied further.

\section{Conclusion}

This paper studied the coding and behaviour of Estonian subjects and subject-like arguments using the multivariate analysis method, which is a precise tool that helped to ensure the comparability of the vaguely similar structures. The theoretical framework that was largely employed in the study was Radical Construction Grammar. To determine the spread of subjecthood in Estonian, I analyzed two different groups of constructions: the constructions that contain the arguments whose subjecthood I measured (intransitive, passive, etc.) and the constructions that I regard reflecting subject properties (case, raising, control, etc.). The paper looked at the measures of subjecthood of ten argument types: the transitive and intransitive subjects, the passive subject, the existential clause noun phrase and the two arguments of the experiencer, possessive and source-marking resultative constructions. By adopting a construction-based approach, each argument was tested against 16 properties that are characteristic of the prototypical, 
unmarked clause active subject (transitive and intransitive clause subjects) but not of the object (objects fails these tests).

As several subjecthood tests that have been used here (case, agreement, control, raising, word order, reflexivization etc.) also distinguish subjects cross-linguistically, the Estonian $\mathrm{A} / \mathrm{S}$ argument may be a suitable candidate to represent the cross-linguistic subject prototype. This should be studied further in future studies.

It was suggested that the Estonian subject-like arguments form a continuum according to their overall subjecthood measure throughout the 16 tests. On the basis of the tests, the global subject category can be said to have a prototype category structure with unmarked transitive and intransitive clause subjects as the prototype. The paper showed that this continuum supports the hypothesis of the Hierarchy of Grammatical Relations Constructions, especially as the Estonian data supports the cross-linguistic generalization that the subject-like coding properties occur on a larger and more diverse set of arguments than the behaviour properties.

The study found that the main factors influencing an argument's subjecthood measure in individual test constructions are topicality and case. However, the overall subjecthood of arguments is divided along a determinant that is a composite one: the Estonian subject-like treatment of arguments tends to depend on the syntactic clause type which includes by definition both topicality and argument structure case frames. To a degree, construction type also seems to play a role on determining arguments' behavioural properties on the constructionspecific level. The subjects of unmarked basic clauses (where the topic is a fully grammaticalized subject) have very high subjecthood scores, while marked clause arguments lack most subjecthood properties or if they share them, their use is less productive. An aspect of subjecthood whose closer treatment was outside the scope of the present work is the distribution of semantic and discourse properties across the behavioural criteria. This could be a focus of future research.

\section{Acknowledgements}

I would like to thank Tania Kuteva, Liina Lindström, Peter Austin, Balthasar Bickel, Abel Zadoks and Alena Witzlack-Makarevich for their extremely helpful comments and feedback. Special thanks for the very useful insights also go to the anonymous reviewer. The responsibility for any errors is of course entirely my own. This study has been funded by the programme Kristjan Jaak (European Social Fund / Ar- 
chimedes Foundation) and the University of Tartu research projects SF0180084s08 "Morphosyntactic structure and development of Estonian" and SF0180056s08 "Language and meaning: semantics and grammar in a cognitive perspective".

\author{
Address: \\ Helena Metslang \\ Institute of Estonian and General Linguistics \\ University of Tartu \\ Jakobi 2 \\ 51004 Tartu, Estonia \\ Tel.: +372 53435845 \\ E-mail: helena.metslang@ut.ee
}

\begin{abstract}
Abbreviations
A - the most actor-like argument in a transitive verb; AG - pronominal clitic or affix referring to the agent of prototypical action verbs; AD - adessive; ALL - allative; Arg - argument; AUX - auxiliary; $\mathrm{BC}$ - Balanced Corpus of the Corpus of Written Estonian; CL clitic; COM - comitative; COMP - comparative; D - pronominal clitic or affix referring to a participant represented by a dative NP; DOM - differential object marking; DSM - differential subject marking; EC - existential clause; ELA - elative; e-NP - the sole argument of the existential clause; ESS - essive; Exp - the experiencer argument of the experiencer construction; $\mathrm{G}$ - genitive; $\mathrm{Gr}$ - the goal argument of the resultative clause; HM - author's example; ILL illative; IMP - imperative; IMPS - impersonal; IN, INE - inessive; INF - infinitive ( $-m a$, - $d a$, - vat forms); M - masculine; MDA - modal adverb; $\mathrm{N}$ - nominative; NEG - negation particle; $\mathrm{O}$ - the not most actor-like argument in a transitive verb; P, part - partitive; PASS passive; $\mathrm{Pe}$ - the possessee argument of the possessive clause; PP preposition phrase; $\mathrm{Pr}$ - the possessor argument of the possessive clause; PR - present tense; PTC - participle; PST, past - past tense, imperfect, Q - question particle, QUO - quotative; S - the sole argument of an intransitive verb; SAP - speech act participant; So the source argument of the resultative clause; St - the stimulus argument of the experiencer clause; SUP - superlative; TERM terminative, TR - translative; V - predicate verb; X - verbal complement. See also Leipzig Glossing Rules http://www.eva.mpg.de/lingua/ resources/glossing-rules.php.
\end{abstract}




\section{References}

Aarts, Bas (2007) Syntactic gradience: the nature of grammatical indeterminacy. Oxford: Oxford University Press.

Barðdal, Jóhanna (2006) "Construction-specific properties of syntactic subjects in Icelandic and German". Cognitive Linguistics 17, 1, 39-106.

Bickel, Balthasar (2003) "Referential density in discourse and syntactic typology". Language 79, 708-736.

Bickel, Balthasar (2004) "The syntax of experiencers in the Himalayas". In: Peri Bhaskararao and Karamuri Venkata Subbarao, eds. Non-nominative subjects, 77 111. Amsterdam and Philadelphia: John Benjamins.

Bickel, Balthasar (2010) "Grammatical relations typology". In Jae Jung Song, ed. The Oxford handbook of language typology, 399-444. Oxford: Oxford University Press.

Croft, William (2001) Radical construction grammar: syntactic theory in typological perspective. Oxford: Oxford University Press.

Erelt, Mati (2004) "Lauseliigendusprobleeme eesti grammatikas". [Some clause structure issues in Estonian grammar.] - In Liina Lindström, ed. Lauseliikmeist eesti keeles, 7-15. [On the grammatical relations in Estonian.] (Tartu Ülikooli eesti keele õppetooli preprindid, 1.) Tartu.

Erelt, Mati (2005) "Source-marking resultatives in Estonian”. Linguistica Uralica 41, $1,20-29$.

Erelt, Mati (2011) "Lisandusi tegumoe käsitlusele". [Additions to the treatment of mood.] Emakeele Seltsi aastaraamat (Tallinn) 57, 25-34

Erelt, Mati, Tiiu Erelt, and Kristiina Ross (2000) Eesti keele käsiraamat. [Handbook of the Estonian language.] Tallinn: Eesti Keele Sihtasutus.

Erelt, Mati and Helle Metslang (2006) "Estonian clause patterns - from Finno-Ugric to standard average European". Linguistica Uralica 42, 4, 254-266.

Erelt, Mati, Reet Kasik, Helle Metslang, Henno Rajandi, Kristiina Ross, Henn Saari, Kaja Tael, and Silvi Vare (1993) Eesti keele grammatika II: Süntaks, lisa: kiri. [Estonian Grammar II. Syntax. Appendix: Script.] Tallinn.

Gil, David (2000) "Syntactic categories, cross-linguistic variation and universal grammar". In P. M. Vogel and B. Comrie, eds. Approaches to the typology of word classes, 173-216. Berlin: Mouton de Gruyter.

Goldberg, Adele E. (1995) Constructions: a construction grammar approach to argument structure. Chicago: University of Chicago Press.

Grewendorf, Günther (1989) Ergativity in German. (Studies in Generative Grammar, 35.) Dodrecht: Foris Publications.

Gries, S. Th. (2003) "Towards corpus-based identification of prototypical instances of constructions". Annual Review of Cognitive Linguistics 1, 1-27.

Hakulinen, Auli (1983) "Subjektikategoria vai nominaalijäsenten subjektimaisuus?". [Subject category and the subjecthood of nominal constituents?] Nykysuomen ra- 
kenne ja kehitys 1, 238-250. [The structure and development of modern Finnish.] Helsinki: Suomalaisen Kirjallisuuden Seura.

Hakulinen, Auli, Maria Vilkuna, Riitta Korhonen, Vesa Koivisto, Tarja Riitta Heinonen, and Irja Alho (2004) Iso suomen kielioppi. [The grammar of Finnish.] Helsinki: Suomalaisen Kirjallisuuden Seura.

Haspelmath, Martin (2002) "Syntactic categories and functional linguistics". In Lecture notes from the course The Nature of Explanation in Linguistics (convened by Martin Haspelmath and Frederick J. Newmeyer). Summer School of the DGfS, Universität Düsseldorf.

Heine, Bernd and Hiroyuki Miyashita (2008) "Accounting for a functional category: German drohen 'to threaten"”. Language Sciences 30, 1, 53-101.

Helasvuo, Marja-Liisa (2001) Syntax in the making: the emergence of syntactic units in Finnish conversation. (Studies in discourse and grammar, 9.) Amsterdam and Philadelphia: John Benjamins.

Helasvuo, Marja-Liisa and Tuomas Huumo, (2010) “Mikä subjekti on?". [What is the subject?] Virittäjä 114, 2, 165-195.

Hiietam, Katrin (2003) Definiteness and grammatical relations in Estonian. Unpublished doctoral Thesis. University of Manchester.

Hopper, Paul J. and Sandra A. Thompson (1980) "Transitivity in grammar and discourse". Language 56, 2, 251-299.

Huumo, Tuomas (1993) "Suomen ja viron kontrastiivista sanajärjestysvertailuja". [Some contrastive word order comparisons of Finnish and Estonian.] In Valma Yli-Vakkuri, ed. Studia comparativa linguarum orbis Maris Baltici. Vol. 1: Tutkimuksia syntaksin ja pragmasyntaksin alalta, 97-158. [Studies of syntax and pragmasyntax.] (Turun yliopiston suomalaisen ja yleisen kielitieteen laitoksen julkaisuja, 43.) Turku.

Huumo, Tuomas (2002) "Syntax or discourse pragmatics: a contrastive analysis on Finnish and Estonian word order”. In L. I. Rábade and S. M Doval Suárez, eds. Studies in contrastive linguistics. Proceedings of the 2nd international contrastive linguistics conference, Santiago de Compostela; October, 2001, 495-502. Santiago de Compostela: Universidade de Santiago de Compostela.

Keenan, Edward (1976) "Towards a universal definition of "subject."” In Charles N. Lee, ed. Subject and Topic, 303-334. New York: Academic Press.

Kiparsky, Paul (1998) "Partitive case and aspect". In Miriam Butt and Wilhelm Geuder, eds. The projection of arguments: lexical and compositional factors, 265-307. Stanford: CSLI Publications.

Koks, Helen (2004) "Subjekti ja objekti käitumisreeglid komplekslauses". [The rules of the subject's and object's behaviour in the complex clause.] In Liina Lindström, ed. Lauseliikmeist eesti keeles, 34-39. [On the grammatical relations in Estonian.] (Tartu Ülikooli eesti keele õppetooli preprindid, 1.) Tartu.

Kroeger, Paul, L (2004) Analyzing syntax: a lexical-functional approach. Cambridge: Cambridge University Press. 
Lambrecht, Knud (1994) Information structure and sentence form: topic, focus, and the mental representations of discourse referents. Cambridge: Cambridge University Press.

Langacker, Ronald W. (1987) Foundations of cognitive grammar. Vol. 1: Theoretical prerequisites. Stanford: Stanford University Press.

Langacker, Ronald W. (1991a) Concept, image, and symbol: the cognitive basis of grammar. Berlin: Mouton de Gruyter.

Langacker, Ronald W. (1991b) Foundations of cognitive grammar. Vol. 2: Descriptive application. Stanford: Stanford University Press.

Lindström, Liina (2002) "Veel kord subjekti ja predikaadi vastastikusest asendist laiendi järel". [On subject and predicate position after the modifier.] Emakeele Seltsi aastaraamat (Tallinn) 47, 87-106.

Lindström, Liina (2004) "Sõnajärg lause tuumargumentide eristajana eesti keeles". [Word order as the distinguisher of the nuclear arguments in the Estonian language.] In Liina Lindström, ed. Lauseliikmeist eesti keeles, 40-49. [On the grammatical relations in Estonian.] (Tartu Ülikooli eesti keele õppetooli preprindid, 1.) Tartu.

Lindström, Liina (2005) Finiitverbi asend lauses. Sõnajärg ja seda mõjutavad tegurid suulises eesti keeles. (Dissertationes philologiae Estonicae Universitatis Tartuensis, 16.) Tartu: Tartu University Press.

Lindström, Liina (2012) "Tundekausatiivikonstruktsioon eesti moodi”. Keel ja Kirjandus (Tallinn) 1, 30-47.

Lindström, Liina, Mervi Kalmus, Anneliis Klaus, Liisi Bakhoff, and Karl Pajusalu (2008) "Ainsuse 1. isikule viitamine eesti murretes". [The first person singular reference in Estonian dialects,] Emakeele Seltsi aastaraamat (Tallinn) 54, 159185.

Matthews, Peter H. (1981) Syntax. Cambridge: Cambridge University Press.

Metslang, Helena (2012) "On the case-marking of existential subjects in Estonian". SKY Journal of Linguistics 25, 151-204.

Metslang, Helena (to appear) "Partitive noun phrases in the Estonian core argument system". In Tuomas Huumo, Silvia Luraghi, eds. Partitives. Proceedings of the Partitives workshop at SLE 43rd Annual meeting in Vilnius. De Gruyter Mouton.

Næss, Åshild (2007) Protoypical transitivity. (Typological Studies in Language, 72.) Amsterdam and Philadelphia: John Benjamins.

Nemvalts, Peep (2000) Aluse sisu ja vorm: alusfraasi käändevaheldus tänapäeva eesti kirjakeeles. [On the content and form of the subject.] Tallinn: Eesti Keele Sihtasutus.

Onishi, Masayuki (2001) "Introduction. Non-canonical subjects and objects: parameters and properties". In Alexandra Aikhenvald, Robert W. M. Dixon, and Masayuki Onishi, eds. Non-canonical marking of subjects and objects, 1-52. (Typological Studies in Languages, 46.) Amsterdam: Benjamins.

Rauh, Gisa (2010) Syntactic categories: their identification and description in linguistic theories. Oxford: Oxford University Press. 
Remmel, Nikolai (1963) "Sõnajärjestus eesti lauses". [Word order in the Estonian sentence.] In Eesti keele süntaksi küsimusi, 216-381. [On the Estonian syntax.] (KKI uurimused, 8.) Tallinn: Eesti Riiklik Kirjastus.

Siewierska, Anna and Dik Bakker (2012) "Three takes on grammatical relations: a view from the languages of Europe and North and Central Asia". In Pirkko Suihkonen, Bernard Comrie, and Valery Solovyev, eds. Argument structure and grammatical relations: a crosslinguistic typology, 295-324. (Studies in Language Companion Series, 126.) Amsterdam: Benjamins.

Tael, Kaja (1988a) Sõnajärjemallid eesti keeles (võrrelduna soome keelega). [Patterns of the word order in Estonian (in comparison with Finnish).] (Preprint. KKI-56.) Tallinn.

Tael, Kaja (1988b) "Infostruktuur ja lauseliigendus". [Information structure and the sentence structure.] Keel ja Kirjandus (Tallinn) 3, 133-143.

Taylor, John R. (1995) Linguistic categorization: prototypes in linguistic theory. 2nd ed. Oxford: Oxford University Press.

Torn-Leesik, Reeli (2009) "The voice system of Estonian". Sprachtypologie und Universalienforschung 62, 1-2, 72-90.

Van Valin, Robert D. (2005) Exploring the syntax-semantics interface. Cambridge: Cambridge University Press.

Van Valin, Robert D. Jr. and Randy J. LaPolla (1997) Syntax: structure, meaning and function. Cambridge: Cambridge University Press.

Vilkuna, Maria (1989) Free word order in Finnish: its syntax and discourse functions. Helsinki: Suomalaisen Kirjallisuuden Seura.

Witzlack-Makarevich, Alena (2011) Typological variation in grammatical relations. Doctoral thesis. Universität Leipzig.

Kokkuvõte. Helena Metslang: Eesti keele subjekti vormistus ja käitumine. Kuna lauseliikmete jagunemine süntaktilistes konstruktsioonides on väga mitmekesine, on tüpoloogilises keeleteaduses tõstetud esile vajadust käsitleda lauseliikmeid konstruktsioonide tasandil ning uurida eraldi, kuidas eri konstruktsioonid lauseliikmeid määratlevad. Käesolev uuring lähenebki subjekti defineerimisele konstruktsioonipõhiselt. Siiski osutub uuringus vajalikuks ka globaalse, konstruktsioonideülese subjekti kategooria kasutamine: subjektilisust vaadeldakse kui omaduste kogumit, mis on eri argumentide juures eri määral esindatud. Uuring on katse rakendada mitmemõõtmelist analüüsi argumentide süntaktilise käitumise uurimisel, mida on seni põhiliselt kasutatud vormistuse uurimiseks. Artikkel sisaldab süsteemset käsitlust eesti keele prototüüpsest subjektist ja subjektisarnastest argumentidest (kokku 10), käsitledes põhjalikult suurt hulka erinevaid vormistus- ja käitumisomadusi (kokku 16). Artikkel väidab, et enamik subjektisarnaseid markeerimata lause argumente ei täida subjekti morfosüntaktilisi kriteeriume või teevad seda 
väga piiratult. Artiklis näidatakse ka, et eesti keele andmed toetavad tüpoloogilise lauseliikmete konstruktsioonide hierarhia hüpoteesi.

Märksõnad: subjekt, subjektisarnane argument, lauseliikmed, vormistus, süntaktiline käitumine, konstruktsioonigrammatika 